\title{
Synthesis of BODIPY-Peptide Conjugates for Fluorescence Labeling of EGFR over-expressing Cells
}

\author{
Ning Zhao ${ }^{1}$, Tyrslai M. Williams ${ }^{1}$, Zehua Zhou ${ }^{1}$, Frank R. Fronczek ${ }^{1}$, Martha Sibrian- \\ Vazquez $^{2}$, Seetharama D. Jois ${ }^{3}$, and M. Graça H. Vicente ${ }^{1, *}$ \\ ${ }^{1}$ Louisiana State University, Department of Chemistry, Baton Rouge LA, 70803, USA \\ 2Portland State University, Department of Chemistry, Portland, OR, 97201, USA \\ ${ }^{3}$ Basic Pharmaceutical Sciences, School of Pharmacy, University of Louisiana at Monroe, Monroe \\ LA, 71201, USA
}

\section{Abstract}

Regioselective functionalization of 2,3,5,6,8-pentachloro-BODIPY 1 produced unsymmetric BODIPY 5, bearing an isothiocyanate group suitable for conjugation, in only four steps. The $\mathrm{X}$ ray structure of 5 reveals a nearly planar BODIPY core with aryl dihedral angles in the range $47.4^{\circ}$ $-62.9^{\circ}$. Conjugation of 5 to two EGFR-targeting pegylated peptides, 3PEG-LARLLT (6) and 3PEG-GYHWYGYTPQNVI (7), under mild conditions (30 min at room temperature), afforded BODIPY conjugates 8 and 9 in 50-80\% isolated yields. These conjugates show red-shifted absorption and emission spectra compared with $\mathbf{5}$, in the near-IR region, and were evaluated as potential fluorescence imaging agents for EGRF over-expressing cells. SPR and docking investigations suggested that conjugate $\mathbf{8}$ bearing the LARLLT sequence binds to EGFR more effectively than 9 bearing the GYHWYGYTPQNVI peptide, in part due to the lower solubility of $\mathbf{9}$, and its tendency for aggregation at concentrations above $10 \mu \mathrm{M}$. Studies in human carcinoma HEp2 cells over-expressing EGFR, demonstrated low dark and photo-cytotoxicities for BODIPY 5 and the two peptide conjugates, and remarkably high cellular uptake for both conjugates $\mathbf{8}$ and $\mathbf{9}$, up to 90-fold compared with BODIPY 5 after $1 \mathrm{~h}$. Fluorescence imaging studies in HEp2 cells revealed subcellular localization of the BODIPY-peptide conjugates mainly in the Golgi apparatus and the cell lysosomes. The low cytotoxicity of the new conjugates and their remarkably high uptake into EGFR over-expressing cells renders them promising imaging agents for cancers overexpressing EGFR.

\section{Graphical Abstract}

"CORRESPONDING AUTHOR: To whom correspondence should be addressed. Phone: 225-578-7405. Fax: 225-578-3458 vicente@1su.edu.

Supporting Information Available: ${ }^{1} \mathrm{H},{ }^{13} \mathrm{C}$ and ${ }^{11} \mathrm{~B}$ NMR spectra for all BODIPYs, HPLC traces and conditions, absorption and emission spectra, concentration-dependent dark and phototoxicity graphs. This material is available free of charge via the Internet at http://pubs.acs.org. 


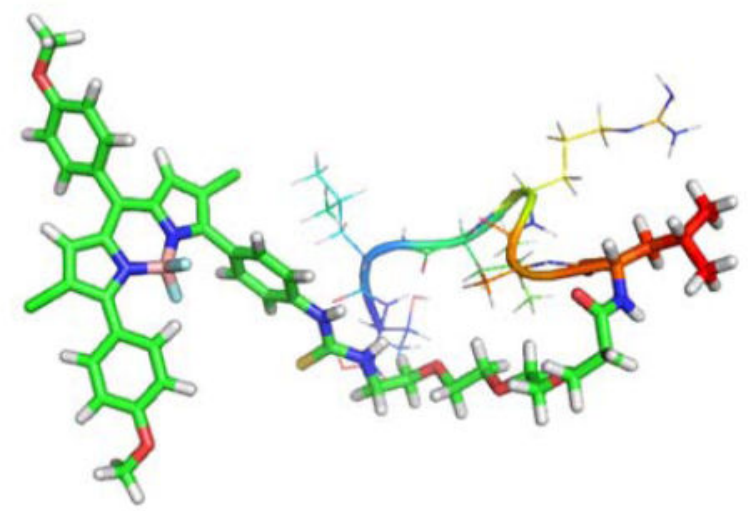

\section{INTRODUCTION}

Epidermal growth factor receptors (EGFR) are ligand-stimulated cell surface receptors that play an essential role in the regulation of cellular functions, including in cell proliferation and survival. ${ }^{1-4}$ Over-expression and/or mutation of EGFR can lead to unregulated growth stimulation and tumorigenesis in various tumor types, including lung, breast, brain, prostate, and colon tumors. ${ }^{5-8}$ The frequent activation of EGFR in these cancers makes them highly attractive diagnostic and therapeutic targets. We have been particular interested in targeting colorectal cancer (CRC), which is the third leading cause of cancer-related deaths in the US, causing approximately 50,000 deaths each year. ${ }^{9}$ Recent studies show that CRC age-specific risk is on the rise, and early screening and diagnosis are essential to address this trend. ${ }^{10}$ Current methods for CRC diagnosis, including different types of colonoscopy and radiography, have relatively low sensitivity for detection of small adenomas $(<5 \mathrm{~mm})$ in the early stages of CRC, when there are no outward symptoms in patients. ${ }^{11}$ Since EGFR is over-expressed on small cancers $(<5 \mathrm{~mm})$ and on the flat, dysplastic, aberrant crypt foci that precede cancer development that are often missed by standard colonoscopy, the molecular targeting of EGFR is a valuable tool in CRC diagnosis and treatment. ${ }^{12}$

In the last two decades, in addition to using the native ligand epidermal growth factor (EGF) ${ }^{13}$ several alternative methodologies have been developed for targeting the extra or the intra-cellular domains of EGFR, ${ }^{2}$ including the monoclonal antibody Cetuximab, ${ }^{14-16}$ single-chain anti-EGFR ScFvEGFR, ${ }^{17}$ anti-EGFR affibody, ${ }^{18-19}$ readily available small peptides, ${ }^{20-27}$ and non-peptidic tyrosine kinase inhibitors. ${ }^{28}$ Among these strategies, peptide ligands with short sequences are particularly attractive for targeting the EGFR protein for a variety of reasons, including their low cost, readily availability, low immunogenicity, relatively fast diffusion rates, ease of modification, as well as their ease of conjugation to various molecules. Two peptides (Figure 1) selected using computer-assisted design or by screening phage display libraries, LARLLT (designated "D4" or EGFR-L1) and YHWYGYTPQNVI (designated "GE11" or EGFR-L2), have demonstrated particularly efficient binding to the extracellular domain of EGFR over-expressed on cancers cells, both in vitro (e.g. SKBR-3 and BT-474 cells) and in vivo (e.g. mice with A431 tumors)..$^{20,22-27,29-30}$ Additionally, computational studies ${ }^{20,25-26}$ have modeled the binding of these two peptides to the extracellular domain at two different binding sites: EGFR-L2 
binds to the EGF binding pocket, while EGFR-L1 binds near domain I, away from the EGF binding pocket.

4,4-Difluoro-4-bora-3a,4a-diaza-s-indacene dyes (known as boron dipyrromethenes, or BODIPYs) are versatile compounds with highly tunable structures that allow the modulation of their stability, solubility and spectroscopic properties, ${ }^{31-35}$ making them suitable for various applications, including in fluorescence imaging, ${ }^{36-40}$ photodynamic therapy (PDT) ${ }^{41-46}$ boron neutron capture therapy (BNCT), ${ }^{47-48}$ and in dye-sensitized solar cells (DSSC) ${ }^{49-51}$ Functionalized BODIPYs can be conjugated to peptides or proteins for imaging applications using "click" reactions, ${ }^{44,52-54}$ traditional amide bond formation reactions, ${ }^{30,55-58}$ or solid support methodologies. ${ }^{59}$ However, several challenges have hindered their applications using these conjugation methods. Bio-orthogonal "click" reactions usually provide high yields of the targeted conjugates, however, the introduction of azide or ethynyl groups at the BODIPY or peptide periphery requires several steps, and it is normally expensive and time consuming. On the other hand, conjugation reactions using traditional coupling reagents often require an additional activation step and long reaction times (up to $24 \mathrm{~h}$ ), giving the targeted conjugates in relatively low yields. In solid-supported synthesis, the resin cleavage step often requires harsh conditions, for example using TFA and/or elevated temperatures, which can remove the $\mathrm{BF}_{2}$ moiety from the BODIPYs. Perhaps the most attractive alternative strategy consists on the introduction of an isothiocyanato moiety on the BODIPY scaffold as an amino reactive group, for the conjugation of various active molecules to BODIPYs including peptides, ${ }^{60-63}$ proteins, ${ }^{54,64-66}$ and other molecules, ${ }^{53,57,67-71}$ due to the short reaction times and high product yields. ${ }^{62,72}$

Herein we describe the synthesis of unsymmetric BODIPY 5 bearing a single isothiocyanato group, from pentachloro-BODIPY $\mathbf{1}$ in only four steps. We show that BODIPY 5 readily reacts with pegylated peptides (3PEG-EGFR-L1 and 3PEG-EGFR-L2) providing EGFRtargeted BODIPY-L1 8 and BODIPY-L2 9 in good yields. These BODIPY-peptide conjugates were investigated as EGFR-targeted fluorescence imaging agents. The binding interactions of conjugates $\mathbf{8}$ and $\mathbf{9}$ to the EGFR protein were investigated by SPR and modeled using Autodock. The uptake, distribution and cytotoxicity of conjugates $\mathbf{8}$ and $\mathbf{9}$ in human carcinoma HEp2 cells over-expressing EGFR were evaluated and compared with those for unconjugated BODIPY 5.

\section{RESULTS AND DISCUSSION}

\section{Synthesis}

We have recently reported the synthesis of versatile polyhalogenated BODIPY platforms, and investigated their reactivity under different reaction conditions. ${ }^{73-76}$ Such BODIPY platforms contain halogen groups with distinct reactivity, allowing for the regioselective functionalization of the BODIPY periphery using various $\operatorname{Pd}(0)$-catalyzed coupling or nucleophilic elimination/addition reactions. For example, the reactivity order of the chloro groups in pentachloro-BODIPY 1 was shown to be: $8-\mathrm{Cl}>3,5-\mathrm{Cl}>2,6-\mathrm{Cl}$, which allows for the stepwise and regioselective functionalization of the 8-position, followed by the 3 and/or 5 positions, and finally the 2 and/or 6 positions of this BODIPY platform. ${ }^{76-77}$ 
The starting material 2,3,5,6,8-pentachloro-BODIPY 1 was prepared by chlorination of 8chloro-BODIPY using TCCA/ACOH, as previously reported. ${ }^{76}$ The key precursor BODIPY $\mathbf{5}$ bearing an isothiocyanato group was prepared from BODIPY $\mathbf{1}$ in four steps, as shown in Scheme 1. A Suzuki-type coupling reaction between 1 and 5 equiv of 4methoxyphenylboronic acid, in the presence of $\mathrm{Pd}\left(\mathrm{PPh}_{3}\right)_{4}$ and $1 \mathrm{M} \mathrm{Na}_{2} \mathrm{CO}_{3}(\mathrm{aq})$, gave 3,8disubstituted BODIPY 2 as the major product, in $45 \%$ isolated yield, after $5 \mathrm{~h}$ reflux in toluene. This reaction was carefully monitoring by TLC and mass spectrometry, which showed the initial formation of the 8-substituted BODIPY, prior to that of the targeted product. The 4-nitrophenyl group was then introduced at the 5-position of BODIPY 2 using another Suzuki coupling reaction using 5 equiv of 4-nitrophenylboronic acid and $\mathrm{Pd}\left(\mathrm{PCy}_{3}\right) \mathrm{G} 2$ as the catalyst, to provide BODIPY 3 in $60 \%$ yield. The use of $\mathrm{Pd}\left(\mathrm{PPh}_{3}\right)_{4}$ in place of $\mathrm{Pd}\left(\mathrm{PCy}_{3}\right) \mathrm{G} 2$ gave lower yields of the targeted product. This is probably due to the relatively lower reactivity of 4-nitrophenylboronic acid, and the slower oxidative addition step under the catalysis of $\mathrm{Pd}\left(\mathrm{PPh}_{3}\right)_{4}$, as previously observed. ${ }^{76}$ The reduction of the nitro group of BODIPY 3 using $\mathrm{Pd}(0) / \mathrm{C}$ and hydrazine in ethanol, ${ }^{78}$ provided the aminefunctionalized BODIPY 4 in $92 \%$ yield. Treatment BODIPY 4 with an excess amount of $1,1^{\prime}$-thiocarbonyldi-2 $(1 \mathrm{H})$-pyridone (TDP) in $\mathrm{CH}_{2} \mathrm{Cl}_{2}$ gave the desired isothiocyanatoBODIPY 5 in $88 \%$ yield. The structures of all BODIPYs were confirmed by ${ }^{1} \mathrm{H} N M R,{ }^{13} \mathrm{C}$ NMR, ${ }^{11}$ B NMR and HRMS (ESI-TOF) methods.

A suitable crystal of BODIPY 5 for X-ray analysis was obtained by slow evaporation from chloroform. The result is shown in Figure 2, the first structure in the Cambridge Structural Database of an isothiocyanato-functionalized BODIPY. The 12-atom BODIPY core is reasonably planar, exhibiting a mean deviation of $0.061 \AA$. The 8-methoxyphenyl substituent is twisted out of the BODIPY plane, and it forms a dihedral angle of $47.4^{\circ}$ with the BODIPY core, as is characteristic of 8-aryl substituents on 1,7-unsubstituted BODIPYs. On the other hand, the substituents at the 3 and 5 positions form slightly larger dihedral angles with the BODIPY core, that for the NCS-phenyl being $54.5^{\circ}$ and for the OMe-phenyl being $62.9^{\circ}$. The average $\mathrm{C}-\mathrm{Cl}$ distance is $1.706 \AA$. As expected the NCS group is essentially linear, with N-C-S angle $174(2)^{\circ}$, but it bonds slightly nonlinearly to the phenyl group, the angle about $\mathrm{N}$ being $168(2)^{\circ}$. It also tilts slightly out of the plane of the phenyl group, with the $\mathrm{N}$ atom $0.08 \AA$ out of plane, the $\mathrm{C}$ atom $0.30 \AA$ and the $\mathrm{S}$ atom $0.68 \AA$.

Two peptide ligands, EGFR-L1 and EGFR-L2, have been shown to specifically target EGFR over-expressing tumor cells both in vitro and in vivo. ${ }^{26,27}$ We have previously reported the conjugation of EGFR-L1 and EGFR-L2 to a porphyrin ${ }^{79}$ and a phthalocyanine ${ }^{26}$ macrocycles, using both short (up to 5-atom) and long (up to 20-atom) linkers. PEG linkers, particularly the low molecular weight triethylene glycol, were shown to increase the solubility and cellular uptake of the conjugates, while preserving the fluorescent properties of the dye, due to their relatively low flexibility compared with higher molecular weight PEG groups. Furthermore, PEG linkers have been shown to increase the specificity for affinity-based molecules for surface sites. ${ }^{80}$ In addition, the triethylene glycol linker is expected to decrease the steric effects of the $N$-terminus of the peptide with the BODIPYNCS 5, leading to higher yields of the targeted conjugates, and to favor extended conformations of the BODIPY-peptide conjugates that could lead to enhanced EGFR 
binding affinity. ${ }^{26,81-82}$ The pegylated peptides tri(ethylene)glycol-LARLLT (PEG3-EGFRL1, 6) and tri(ethylene)glycol-GYHWYGYTPQNVI (PEG3-EGFR-L2, 7) were synthesized by solid phase peptide synthesis (SPPS) on a Fmoc-Pal-PEG-PS resin using TBTU, HOBt, and DIEA as the coupling reagents, to yield the parent peptides LARLLT and GYHWYGYTPQNVI, respectively, as previously reported. ${ }^{11 \mathrm{~g}, 35}$ The resulting peptides were then reacted with Fmoc-NH-PEG3-propionic acid to yield peptides 6 and 7. In the final step, the peptide was deprotected of the Fmoc group using a 20\% piperidine solution, and then cleaved from the resin with a cocktail consisting of TFA (94\%), Millipore water (2.5\%), liquefied phenol (2.5\%) and Tris (1\%). Purification by reverse phase HPLC gave the corresponding pegylated peptides in $38-39 \%$ yields.

The pegylated peptides 6 and $\mathbf{7}$ reacted with BODIPY-NCS 5 in anhydrous DMF and in the presence of TEA, at room temperature for $30 \mathrm{~min}$, to provide the corresponding conjugates 8 and 9 in 80 and 50\% yields, respectively, as shown in Scheme 2. Longer reaction times (up to 24 hours) led to lower product yields, by favoring side reactions. Under these reaction conditions the BODIPY platform was preserved, as confirmed by ${ }^{11} \mathrm{~B}-\mathrm{NMR}$, which showed triplets for the $\mathrm{BF}_{2}$ groups at $\delta=0.368$ and $0.374 \mathrm{ppm}$ for $\mathbf{8}$ and $\mathbf{9}$, respectively. The BODIPY-peptide conjugates were further characterized by ${ }^{1} \mathrm{H}$ NMR, HSQC, and MALDITOF.

\section{Spectroscopic properties}

The spectroscopic properties of BODIPYs $\mathbf{3}, \mathbf{4}$, and $\mathbf{5}$ in dichloromethane, and of peptide conjugates $\mathbf{8}$ and $\mathbf{9}$ in DMSO, including their maximum absorption $\left(\lambda_{\mathrm{abs}}\right)$ and emission $\left(\lambda_{\mathrm{em}}\right)$ wavelengths, Stokes' shifts, fluorescence quantum yields $\left(\Phi_{\mathrm{f}}\right)$, and molar extinction coefficients $(\log \varepsilon)$, were investigated and the results are summarized in Tables 1 and S1. Figures 3 and $\mathrm{S} 1$ show the normalized absorption and emission spectra for the BODIPYs and the conjugates. All BODIPYs showed characteristic strong absorption bands ( $\log \varepsilon=$ $4.3-4.7)$ in the range of $613-634 \mathrm{~nm}$ attributed to the $S_{0}-S_{1}\left(\pi-\pi^{*}\right)$ transitions. The weaker absorption bands centered around $450 \mathrm{~nm}$ are attributed to $S_{0}-S_{n}(n \geq 2)$ transitions. The Stokes shift was smallest for $\mathbf{4}(19 \mathrm{~nm})$ bearing the electron-donating amino group, and in the range of 41-48 nm for all other BODIPYs. As previously reported, the largest molecular orbital coefficients are located at the BODIPY 3 and 5 positions. ${ }^{34}$ Therefore, the reduction of the nitro group of BODIPY 3 led to 36 and $14 \mathrm{~nm}$ red-shifts in the absorption and emission bands of $\mathbf{4}$, respectively, due to the electron-donating character of the paraaminophenyl group. In addition, this reduction also caused a significant decrease in the BODIPY's fluorescence quantum yield due to reductive photoinduced electron transfer (aPeT) ${ }^{33}$ On the other hand, BODIPY-NCS 5 shows only slightly red-shifted absorption and emission bands (by $3 \mathrm{~nm}$ ) compared with 3 bearing a para-nitrophenyl group (see Figure S1).

As shown in Figure 3, BODIPY-peptide conjugates 8 and 9 have slightly broader absorption and emission bands compared with their precursor BODIPY-NCS 5, and red-shifted by 11$13 \mathrm{~nm}$, caused by the replacement of the linear isothiocyanato group with a thioamide group. As a consequence, both conjugates 8 and 9 show emissions at $634 \mathrm{~nm}$ in the near-infrared region of the optical spectrum, characterized by reduced autofluorescence and absorption by 
tissues, and with better penetration through tissues than visible light. However, the fluorescence quantum yield for $\mathbf{8}$ and $\mathbf{9}$ decreased by 5 to 10 -fold compared with $\mathbf{5}$, also due to the introduction of the flexible pegylated peptide chains that lead to increased nonradioactive decay. ${ }^{84}$ Nevertheless, conjugates $\mathbf{8}$ and $\mathbf{9}$ were still efficient in cell imaging investigations (vide infra).

\section{SPR studies}

To evaluate the binding of peptides and BODIPY-peptide conjugates to the EGFR protein, $\mathrm{SPR}^{85-86}$ studies were carried out and the results are shown in Figures 4 and S10. Pegylated peptides $\mathbf{6}$ and $\mathbf{7}$ exhibited binding to EGFR with fast kinetics of association and dissociation as shown in Figure 4a,b. For peptide $\mathbf{6}$ at $100 \mu \mathrm{M}$ the response was around 20 units, whereas for peptide 7 at the same concentration the response was around 150 units, suggesting a significantly higher binding affinity for $\mathbf{7}$ compared with $\mathbf{6}$. In the case of conjugate $\mathbf{8}$ two modes of binding were observed. At lower concentrations up to $100 \mu \mathrm{M}$ the response increased by 400 units and saturation was reached. However, further addition of compound 8 resulted in a drastic increase of the SPR signal (nearly 2000 units), as seen in Figure 4c. At higher concentrations, the kinetics of association and dissociation suggest specific binding of 8 to EGFR, as seen by the slow increase in the SPR signal. On the other hand, in the case of conjugate $\mathbf{9}$, the SPR signal was saturated at only $10 \mu \mathrm{M}$ concentration of the compound, and the relative increase in response was less than 10 units (Figure 4d), suggesting weak or non-specific binding of this conjugate. To verify the non-specific binding, BODIPY 5 was also used as an analyte in SPR studies (see Supporting Information, Figure S10). BODIPY 5 also indicated binding similar to conjugate $\mathbf{9}$, suggesting that the BODIPY probably binds to EGFR non-specifically, along with peptide $\mathbf{7}$. However, peptide 7 exhibited specific binding as shown in Figure $4 \mathrm{~b}$. Therefore, the addition of BODIPY to peptide $\mathbf{7}$ appears to reduce the specificity of binding to EGFR. This could be due to the poor solubility of conjugate $\mathbf{9}$, and its tendency for aggregation at concentrations above $10 \mu \mathrm{M}$. We have previously observed that zinc(II) phthalocyanine-EGFRL2 conjugates linked via short 5-atom carbon or tri(ethylene)glycol spacers also show reduced EGFR-targeting and poor solubility in aqueous solutions. ${ }^{26}$

\section{HEp2 Cell Studies}

Human squamous cell carcinoma HEp2 with EGFR over-expression ${ }^{11 \mathrm{~g}, 87}$ is a convenient model cell line for evaluation of the cytotoxicity, cellular uptake, and subcellular distribution of BODIPY 5 and the peptide conjugates $\mathbf{8}$ and $\mathbf{9}$. The Cell Titer Blue assay was used to evaluate the cytotoxicity, both in the dark and after exposure to $1.5 \mathrm{~J} / \mathrm{cm}^{2}$ light dose, and the results obtained are summarized in Table 2, and shown in Figures S2 and S3. The least toxic BODIPY was unconjugated $\mathbf{5}$, with $\mathrm{IC}_{50}$ values, obtained from dose-response curves, above $100 \mu \mathrm{M}$. The BODIPY-peptide conjugates were slightly more toxic, particularly $\mathbf{8}$, although both conjugates still revealed low cytotoxicities in the dark $\left(\mathrm{IC}_{50}>98 \mu \mathrm{M}\right)$ and upon exposure to low light dose $\left(\mathrm{IC}_{50}>74 \mu \mathrm{M}\right)$. The slightly higher cytotoxicity of conjugate 8 may be due to its positive charge on the peptide sequence, which favors a fast and efficient intracellular uptake, in agreement with previous observations with phthalocyanine-EGFR-L1 conjugates. ${ }^{26}$ The low dark and photo cytotoxicities observed for the new conjugates are an 
important feature for their application as molecular imaging agents for early detection of cancers over-expressing EGFR.

The time-dependent cellular uptake for BODIPYs $\mathbf{5 , 8}$ and $\mathbf{9}$ was performed at the concentration of $10 \mu \mathrm{M}$ in HEp2 cells, and the results are shown in Figure 5 and Table S2. At concentrations higher than $10 \mu \mathrm{M}$ conjugate $\mathbf{9}$ has tendency for aggregation, as observed in the SPR investigations. Both BODIPY-peptide conjugates $\mathbf{8}$ and $\mathbf{9}$ showed remarkably higher cellular uptake compared with unconjugated BODIPY 5, at all time points investigated, suggesting that these conjugates actively target the EGFR over-expressed in this cell line. Indeed, after $1 \mathrm{~h}$, conjugates 8 and 9 accumulated 90 -fold and 60-fold higher, respectively, than unconjugated BODIPY $\mathbf{5}$, and after $24 \mathrm{~h}$ both conjugates accumulated about 30 -fold higher than $\mathbf{5}$. These remarkable differences indicate that both peptide sequences, and in particular EGFR-L1, have a strong effect on the cell targeting and uptake ability of the BODIPY conjugates. ${ }^{88}$ In addition, the presence of the triethylene glycol groups in $\mathbf{8}$ and $\mathbf{9}$ and their enhanced solubility compared with $\mathbf{5}$, favor their cellular uptake. Conjugate 9 bearing a longer peptide sequence with 11 hydrophobic and two polar amino acids (Figure 1) has increased hydrophobicity compared $\mathbf{8}$ bearing the shorter peptide sequence with 4 hydrophobic, one polar, and one cationic amino acids.

Conjugates 8 and 9 showed different uptake kinetics, with 8 bearing the cationic EGFR-L1 peptide, accumulating at a much faster rate in the first $8 \mathrm{~h}$, after which a plateau was reached. On the other hand, conjugate 9 containing a longer and more hydrophobic EGFRL2 sequence, accumulated at a slower rate during the first $8 \mathrm{~h}$, but its cellular uptake continued to increase during the time investigated, and up to the $24 \mathrm{~h}$ evaluated in this study. This is likely due to the enhanced ability of conjugate $\mathbf{8}$ bearing the shorter EGFR-L1, to quickly permeate across the negatively charged plasma membrane, as a result of its cationic charge, as well as its lower molecular weight and increased solubility compared with conjugate 9.

Fluorescence microscopy was performed to evaluate the major and minor sites of localization of BODIPY 5 and conjugates 8 and $\mathbf{9}$ in HEp2 cells, and the results are shown in Figures 6, 7, and S4, and summarized in Table 2. Despite the low fluorescence quantum yields, a clear fluorescent signal is observed by microscopy, suggesting that these conjugates can be used for fluorescence imaging of EGFR-expressing cells. The observed fluorescence signal was mainly intracellular, indicating that the BODIPY conjugates do not appear to localize on the plasma membrane, probably as a result of their fast internalization. In the colocalization experiments, the organelle-specific ER Tracker Blue/White (ER), BODIPY Ceramide (Golgi), MitoTracker Green (mitochondria), and LysoSensor Green (lysosomes) were used. The BODIPY-peptide conjugates localized mainly in the Golgi apparatus and the cell lysosomes (Figures 6f,j and 7f,j), whereas BODIPY 5 was preferentially found in the ER and the Golgi apparatus (Figure S4d,f). Indeed, BODIPY dyes are often found in ER and Golgi, ${ }^{47,89}$ and conjugates $\mathbf{8}$ and $\mathbf{9}$ also localized, to a smaller extent, in the ER (Figures 6d, 7d). Interestingly, conjugates $\mathbf{8}$ and $\mathbf{9}$, in contrast to BODIPY $\mathbf{5}$, were also found in the cell lysosomes. Lysosomal localization is often observed in fluorophore-peptide conjugates, probably as a result of an endocytic mechanism of cell internalization for this type of conjugate, as we have previously observed for a phthalocyanine conjugated to EGFR-L1 and 
EGFR-L2. ${ }^{11 g}$ In addition, conjugate $\mathbf{8}$ was found to localize to a smaller extent in the mitochondria, and this might explain its observed slightly higher cytotoxicity compared with 5 and $\mathbf{8}$ (Table 2).

\section{Modeling and Docking}

To visualize the binding interaction of conjugates $\mathbf{8}$ and $\mathbf{9}$ with EGFR, three-dimensional structures of the compounds were generated using InsightII molecular modeling software (Figure 8) and the conjugates were docked to the EGFR structure using Autodock software. ${ }^{90}$ The peptide LARLLT in conjugate $\mathbf{8}$ is known to bind to EGFR near domain I, as indicated in previous studies. ${ }^{25-26}$ The lowest energy docked structure of compound $\mathbf{8}$ is shown in Figure 7A with docking energy of $-4.19 \mathrm{kcal} / \mathrm{mol}$. The docked structure formed three hydrogen bonding interactions with the EGFR protein, namely the peptide $\mathrm{NH}$ of L5 formed an hydrogen bond with the carbonyl group of Ser222 from EGFR, the NH of L1 formed an hydrogen bond with the carbonyl group of Gln59, and one oxygen atom of the PEG linker formed an hydrogen bond interaction with Asn119 of EGFR. The BODIPY core of conjugate $\mathbf{8}$ formed hydrophobic interactions with the following residues on EGFR: Leu186, Pro171, Lys185 side chain, Ile189 and 190. The BODIPY group was extended away from the peptide binding pocket, likely forming non-specific hydrophobic interactions with the EGFR surface.

Figure 7B shows the binding of conjugate 9 to EGFR near the EGF binding pocket. ${ }^{20}$ Compound 9 binds to the lower side of the EGF binding pocket with a docking energy of $-6.07 \mathrm{kcal} / \mathrm{mol}$, forming three hydrogen bonds. The G6 and T8 side chain of the peptide formed hydrogen bond interactions with the side chain of Arg310 on the EGFR. The peptide residue Y2 also formed an hydrogen bond interaction with Val312 of EGFR. The PEG chain was folded in a loop structure and it was not involved in any hydrogen bond interactions with the receptor. The BODIPY core of conjugate $\mathbf{9}$ is located on a hydrophobic pocket near Phe335 and His334 of EGFR. The alpha 4-methoxyphenyl group on the BODIPY is enfolded in the hydrophobic pocket of EGFR, stabilizing the structure of conjugate 9 in the EGF binding pocket. The BODIPY core extends out of the EGF deep binding pocket, while the peptide chain remains inside the EGF binding site.

SPR and docking studies suggest that conjugate $\mathbf{8}$ bearing the EGFR-L1 sequence binds specifically to EGFR, at a site away from EGF binding pocket. On the other hand, conjugate 9 binds near the EGF binding pocket, with the BODIPY core buried in a hydrophobic pocket and extended out of the pocket. These results are in agreement with previous studies ${ }^{20}$ suggesting that the EGFR-L2 peptide binds near the EGF binding pocket, partially overlapping with the EGF binding pocket. Our docking studies demonstrate that conjugate 9 binds to the lower side of EGFR, in the EGF binding pocket. Furthermore, SPR studies indicated that BODIPY 5 binds to EGFR non-specifically (Figure S10) and the binding of conjugate 9 seems to be non-specific at concentrations greater than $10 \mu \mathrm{M}$ (Figure $4 \mathrm{~d}$ ). This may be due to the lower solubility and tendency for aggregation of $\mathbf{9}$ at concentrations above $10 \mu \mathrm{M}$, and to the binding of the BODIPY core to the hydrophobic pocket near the EGF binding pocket. Furthermore, modeling studies suggest that in the case of conjugate $\mathbf{8}$, the PEG linker and BODIPY core do not mask the amino acid functional groups in the peptide, 
whereas in conjugate 9 the PEG linker folds back onto the peptide surface, masking some or part of the amino acid side chains in the EGFR-L2 peptide (Figure 7). Therefore, conjugate 8 appears to be superior for the specific targeting and binding to EGFR, which is also in agreement with the SPR and cellular studies.

\section{CONCLUSIONS}

We report an expedite synthesis of BODIPY $\mathbf{5}$, bearing an isothiocyanate group, in four steps from 2,3,5,6,8-pentachloro-BODIPY 1, via two regioselective Suzuki cross-coupling reactions, followed by reduction with $\operatorname{Pd}(0)$ /hydrazine in ethanol, and conversion to the isothiocyanate functionality using $1,1^{\prime}$-thiocarbonyldi-2(1H)-pyridone in $\mathrm{CH}_{2} \mathrm{Cl}_{2}$. The structures of all BODIPYs were confirmed by NMR, HRMS, and in the case of 5, by X-ray crystallography. The reaction of the isothiocyanate-BODIPY 5 with two pegylated EGFRtargeting peptides, 3PEG-LARLLT and 3PEG-GYHWYGYTPQNVI, proceed smoothly at room temperature for $30 \mathrm{~min}$, providing the corresponding BODIPY-peptide conjugates 8 and $\mathbf{9}$ in $50-80 \%$ isolated yields. The structures of $\mathbf{8}$ and $\mathbf{9}$ were investigated by NMR, HSQC, MALDI-TOF and molecular dynamics. BODIPY conjugates 8 and $\mathbf{9}$ showed absorption and emissions in the red and near-infrared regions of the spectrum, at ca. 588 and $634 \mathrm{~nm}$ respectively, and fluorescence quantum yields in the range $\Phi_{\mathrm{f}}=0.01-0.033$ in DMSO. SPR investigations indicated that while conjugate $\mathbf{8}$ binds specifically to EGFR at concentrations up to $250 \mu \mathrm{M}$, conjugate 9 showed non-specific binding to EGFR at concentrations above $10 \mu \mathrm{M}$ due to its tendency for aggregation. The binding modes of BODIPY-peptide conjugates were investigated using Autodock. These studies suggest that 9 binds to the lower side on the EGF binding pocket group, while $\mathbf{8}$ binds near domain I of EGFR, away from the EGF binding pocket. The BODIPY moiety in these conjugates is involved in non-specific hydrophobic interactions with the EGFR surface. Studies in human HEp2 cells over-expressing EGFR revealed low cytotoxicity for the BODIPY conjugates, and remarkable EGFR-targeting ability and cellular uptake, up to 90-fold that of unconjugated BODIPY 5. The Golgi apparatus and cell lysosomes were the main sites of intracellular localization for the conjugates, whereas the unconjugated BODIPY localizes mainly in the ER and the Golgi apparatus. Our studies show that these BODIPY-peptide conjugates, in particular $\mathbf{8}$, effectively target and bind to EGFR, and despite their relatively low fluorescence quantum yields, can be used for fluorescence imaging of cells overexpressing EGFR. Further investigations of EGFR-targeted molecular imaging agents with red-shifted emissions for increased penetration through tissues and reduced interference from auto-fluorescence, are currently being investigated in our laboratories.

\section{EXPERIMENTAL SECTION}

\section{Synthesis}

Commercially available chemicals were purchased from VWR or Sigma-Aldrich and used without further purification. Thin layer chromatography (TLC) was performed on the precoated silica gel plates $(0.2 \mathrm{~mm}, 254$ indicator, polyester backed, $60 \AA$, Sorbent Technologies) to monitor the reactions. Preparative TLC plates (60G, VWR) and silica gel (60Å, 230-400 mesh, Sorbent Technologies) were used for liquid chromatography and 
column chromatography. ${ }^{1} \mathrm{H}$ NMR and ${ }^{13} \mathrm{C}$ NMR spectra were collected on a Bruker AV-400 liquid, or AV-500 spectrometer at $300 \mathrm{~K}$. The chemical shifts $(\delta)$ are provided in parts per million (ppm) in $\mathrm{CDCl}_{3}$ (7.27 ppm for ${ }^{1} \mathrm{H}$ NMR and $77.0 \mathrm{ppm}$ for ${ }^{13} \mathrm{C} \mathrm{NMR}$ ) and DMSO (2.54 ppm for ${ }^{1} \mathrm{H}$ NMR). The coupling constants $(J)$ are reported in Hz. Highresolution mass spectra (HRMS) and MALDI (TOF) spectra were obtained on a 6210 ESITOF Mass Spectrometer (Agilent Technologies) under negative mode and Applied Biosystems QSTAR at the LSU Mass Spectrometry Facility. Normal-phase HPLC was performed on a Dionex system (organics system) including a P680 pump with a UVD 340 detector and a fraction collector III. This system is connected to a Dynamax axial compression column in the packing of irregular silica gel (Rainin $60 \AA$ A). Reversed-phase HPLC analysis was performed with a Waters 2485 Quaternary Gradient Module, Waters Sample Injector, and 2489 UV/Visible detector which are controlled by Waters Empower 2 software. Separations were completed on an X-Bridge BEH300 Prep C18 (5 um, $10 \times 250$ $\mathrm{mm})$ with an X-Bridge BEH300 Prep Guard cartridge $300 \AA(5 \mathrm{um}, 10 \times 10 \mathrm{~mm})$ at a 4 $\mathrm{mL} / \mathrm{min}$ flow rate with UV detection for peptides at $220 \mathrm{~nm}$, and for BODIPY conjugates at $580 \mathrm{~nm}$. Fractions of HPLC purity (> 95\%) with the anticipated mass were combined and lyophilized.

2,3,5,6,8-Pentachloro-BODIPY 1 was prepared by using our published procedure. ${ }^{76}$

BODIPY 2-Into a $25 \mathrm{~mL}$ round-bottomed flask were added BODIPY 1 (36.4 mg, 0.1 mmol) and $3 \mathrm{~mol} \%$ of $\mathrm{Pd}\left(\mathrm{PPh}_{3}\right)_{4}$. The flask was evacuated and refilled with nitrogen three times. Toluene $(4 \mathrm{~mL})$ and $2 \mathrm{M} \mathrm{Na}_{2} \mathrm{CO}_{3}(\mathrm{aq})(0.5 \mathrm{~mL})$ were added into mixture. (4Methoxyphenyl)boronic acid ( $38 \mathrm{mg}, 0.25 \mathrm{mmol}$ ) was then added portion-wise. The final mixture was stirred at $100{ }^{\circ} \mathrm{C}$ under nitrogen for $5 \mathrm{~h}$. The reaction was stopped when the targeted di-coupled product was the major product according to TLC, and the mixture was poured into saturated $\mathrm{NaHCO}_{3}(\mathrm{aq})(15 \mathrm{~mL})$ and extracted with $\mathrm{CH}_{2} \mathrm{Cl}_{2}(10 \mathrm{~mL} \times 3)$. The organic layers were combined, washed with brine $(30 \mathrm{~mL})$ and water $(30 \mathrm{~mL})$, and passed through anhydrous $\mathrm{Na}_{2} \mathrm{SO}_{4}$. The organic solvents were removed under reduced pressure and the resulting residue was subjected to column chromatography or prep TLC using $\mathrm{CH}_{2} \mathrm{Cl}_{2}$ / hexanes (1:2) for elution, yielding the desired product $2(22.8 \mathrm{mg}, 45 \%)$. $\mathrm{mp} 210$ $212{ }^{\circ} \mathrm{C} ;{ }^{1} \mathrm{H}$ NMR $\left(500 \mathrm{MHz}, \mathrm{CDCl}_{3}\right) \delta 7.74-7.76(\mathrm{~d}, J=8.7 \mathrm{~Hz}, 2 \mathrm{H}), 7.49-7.51(\mathrm{~d}, J=8.6$ $\mathrm{Hz}, 2 \mathrm{H}), 7.04-7.09$ (m, 4H), 6.97 (s, 1H), $6.81(\mathrm{~s}, 1 \mathrm{H}), 3.93$ (s, 3H), $3.90(\mathrm{~s}, 3 \mathrm{H}) ;{ }^{13} \mathrm{C} \mathrm{NMR}$ $\left(125 \mathrm{MHz}, \mathrm{CDCl}_{3}\right) \delta 162.3,161.4,156.5,143.5,139.2,133.4,132.3,132.00(\mathrm{t}), 130.9$, 129.7, 126.3, 125.1, 123.8, 121.2, 120.1, 114.4, 113.7, 55.6, 55.3; ${ }^{11} \mathrm{~B}$ NMR $(128 \mathrm{MHz}$, $\mathrm{CDCl}_{3}$ ) $\delta 0.270$ (t, $J=28.8 \mathrm{~Hz}$ ); HRMS (ESI-TOF) $\mathrm{m} / \mathrm{z}$ calcd for $\mathrm{C}_{23} \mathrm{H}_{16} \mathrm{BCl}_{3} \mathrm{~F}_{2} \mathrm{~N}_{2} \mathrm{O}_{2}$ $[\mathrm{M}]^{-}$505.0375; found 505.0392.

BODIPY 3-Into a $25 \mathrm{~mL}$ round-bottomed flask were added BODIPY 2 (20.3 mg, 0.04 $\mathrm{mmol})$ and $3 \mathrm{~mol} \%$ of $\mathrm{Pd}\left(\mathrm{PCy}_{3}\right) \mathrm{G} 2$. The flask was evacuated and refilled with nitrogen three times. Toluene $(4 \mathrm{~mL})$ and $2 \mathrm{M} \mathrm{Na}_{2} \mathrm{CO}_{3}(\mathrm{aq})(0.5 \mathrm{~mL})$ were added into mixture. (4Nitrophenyl)boronic acid ( $38 \mathrm{mg}, 0.25 \mathrm{mmol}$ ) was then added portion-wise. The final mixture was stirred at $100{ }^{\circ} \mathrm{C}$ under nitrogen for $3 \mathrm{~h}$. The reaction was stopped when the starting material disappered according to TLC, and the mixture was poured into saturated $\mathrm{NaHCO}_{3}(\mathrm{aq})(15 \mathrm{~mL})$ and extracted with $\mathrm{CH}_{2} \mathrm{Cl}_{2}(10 \mathrm{~mL} \times 3)$. The organic layers were 
combined, washed with brine $(30 \mathrm{~mL})$ and water $(30 \mathrm{~mL})$, and passed through anhydrous $\mathrm{Na}_{2} \mathrm{SO}_{4}$. The organic solvents were removed under reduced pressure and the resulting residue was subjected to column chromatography or prep TLC using $\mathrm{CH}_{2} \mathrm{Cl}_{2} /$ hexanes (1:1) for elution, yielding the desired product $3(14.3 \mathrm{mg}, 60 \%)$. mp $246-248{ }^{\circ} \mathrm{C} ;{ }^{1} \mathrm{H}$ NMR $(500$ $\mathrm{MHz}, \mathrm{CDCl}_{3}$ ) $\delta 8.27-8.29(\mathrm{~d}, J=8.4 \mathrm{~Hz}, 2 \mathrm{H}), 7.84-7.86(\mathrm{~d}, J=8.6 \mathrm{~Hz}, 2 \mathrm{H}), 7.66-7.67$ (d, $J=8.7 \mathrm{~Hz}, 2 \mathrm{H}), 7.56-5.58(\mathrm{~d}, J=8.4 \mathrm{~Hz}, 2 \mathrm{H}), 7.10-7.12(\mathrm{~d}, J=8.4 \mathrm{~Hz}, 2 \mathrm{H}), 7.04(\mathrm{~s}, 1 \mathrm{H})$, 6.97-6.99 (d, $J=8.5 \mathrm{~Hz}, 1 \mathrm{H}), 6.91(\mathrm{~s}, 1 \mathrm{H}), 3.95(\mathrm{~s}, 1 \mathrm{H}), 3.85(\mathrm{~s}, 1 \mathrm{H}) ;{ }^{13} \mathrm{C} \mathrm{NMR}(125 \mathrm{MHz}$, $\left.\mathrm{CDCl}_{3}\right) \delta 162.3,161.3,157.0,148.6,148.1,144.5,136.2,133.6,132.9,132.4,131.9,131.5$, 130.0, 127.0, 125.6, 124.4, 123.1, 121.2, 120.9, 114.4, 113.6, 55.6, 55.3; ${ }^{11} \mathrm{~B}$ NMR (128 $\mathrm{MHz}, \mathrm{CDCl}_{3}$ ) $\delta 0.507$ (t, $J=30.4 \mathrm{~Hz}$ ); HRMS (ESI-TOF) $\mathrm{m} / \mathrm{z}$ calcd for $\mathrm{C}_{29} \mathrm{H}_{20} \mathrm{BCl}_{2} \mathrm{~F}_{2} \mathrm{~N}_{3} \mathrm{O}_{4}[\mathrm{M}]^{-}$592.0934; found 505.0909.

BODIPY 4-BODIPY 3 (11.9 mg, $0.02 \mathrm{mmol}$ ) was dissolved in EtOH/THF (3 mL/0.5 $\mathrm{mL}) . \mathrm{N}_{2}$ was purged into the mixture for $10 \mathrm{~min} .10 \% \mathrm{Pd} / \mathrm{C}(26.6 \mathrm{mg}, 1.25 \mathrm{eq})$ and hydrazine monohydrate $(9.7 \mu \mathrm{L})$ were added. The mixture was stirred and refluxed under $\mathrm{N}_{2}$ atmosphere for $2 \mathrm{~h}$. The reaction was stopped when the starting material disappeared according to TLC. A celite cake was used to remove the catalyst, eluting with ethyl acetate. The residue was subjected to prep TLC using ethyl acetate/hexanes 1:1 for elution to provide the desired product $4(10.9 \mathrm{mg}, 92 \%)$. mp $227-229{ }^{\circ} \mathrm{C} ;{ }^{1} \mathrm{H} \mathrm{NMR}\left(400 \mathrm{MHz}, \mathrm{CDCl}_{3}\right) \delta$ $7.64-7.67(\mathrm{~d}, J=8.7 \mathrm{~Hz}, 2 \mathrm{H}), 7.52-7.67(\mathrm{dd}, J=10.7,8.6 \mathrm{~Hz}, 4 \mathrm{H}), 7.07-7.09$ (d, $J=8.7$ $\mathrm{Hz}, 2 \mathrm{H}), 6.95-6.97$ (d, $J=8.8 \mathrm{~Hz}, 2 \mathrm{H}), 6.91(\mathrm{~s}, 1 \mathrm{H}), 6.87$ (s, 1H), 6.69-6.70 (d, $J=8.6 \mathrm{~Hz}$, $2 \mathrm{H}), 3.94(\mathrm{~s}, 3 \mathrm{H}), 3.85(\mathrm{~s}, 3 \mathrm{H}) ;{ }^{13} \mathrm{C} \mathrm{NMR}\left(126 \mathrm{MHz}, \mathrm{CDCl}_{3}\right) \delta$ 161.8, 160.7, 155.2, 153.1, 148.2, 142.6, 133.0, 132.6, 132.2, 131.9, 128.4, 127.3, 126.1, 122.9, 122.0, 119.1, 114.2, 114.1, 113.5, 55.6, 55.2; ${ }^{11} \mathrm{~B}$ NMR $\left(128 \mathrm{MHz}, \mathrm{CDCl}_{3}\right) \delta 0.63$ (t, $J=30.4 \mathrm{~Hz}$ ); HRMS (ESITOF) $\mathrm{m} / \mathrm{z}$ calcd for $\mathrm{C}_{29} \mathrm{H}_{22} \mathrm{BCl}_{2} \mathrm{~F}_{2} \mathrm{~N}_{3} \mathrm{O}_{2}[\mathrm{M}]^{-}$562.1192; found 562.1175 .

BODIPY 5-Into a $25 \mathrm{~mL}$ round-bottomed flask were added BODIPY 4 (10.2 mg, 0.018 mmol), 1,1' -thiocarbonyldi-2(1H)-pyridone (20.9 mg, $0.09 \mathrm{mmol})$, and dichloromethane (2 $\mathrm{mL}$ ). The mixture was stirred at room temperature for $2 \mathrm{~h}$. The reaction was stopped when the starting material was completely consumed, according to TLC. The organic solvent was removed, and the residue was subjected to prep TLC using ethyl acetate/hexanes 1:2 for elution to provide the desired product 5 (9.6 mg, 88\%). mp 247-249 ${ }^{\circ} \mathrm{C} ;{ }^{1} \mathrm{H}$ NMR (400 $\left.\mathrm{MHz}, \mathrm{CDCl}_{3}\right) \delta$ 7.64-7.69 (m, 4H), 7.54-7.56 (d, $\left.J=8.7 \mathrm{~Hz}, 2 \mathrm{H}\right), 7.27-7.29(\mathrm{~s}, 2 \mathrm{H}), 7.09-$ $7.11(\mathrm{~d}, J=8.7 \mathrm{~Hz}, 1 \mathrm{H}), 6.96-6.98(\mathrm{~m}, 3 \mathrm{H}), 6.90(\mathrm{~s}, 1 \mathrm{H}), 3.95(\mathrm{~s}, 1 \mathrm{H}), 3.86(\mathrm{~s}, 1 \mathrm{H}) ;{ }^{13} \mathrm{C}$ NMR $\left(125 \mathrm{MHz}, \mathrm{CDCl}_{3}\right) \delta 162.2,161.1,155.8,151.0,144.1,136.7,133.3,132.8,132.4$, 132.3, 131.9, 131.7, 129.2, 128.6, 127.4, 125.8, 125.3, 123.6, 121.7, 121.3, 114.3, 113.6, 55.6, 55.2; ${ }^{11} \mathrm{~B}$ NMR (128 MHz, $\mathrm{CDCl}_{3}$ ) $\delta 0.518$ (t, $J=30.3 \mathrm{~Hz}$ ); HRMS (ESI-TOF) m/z calcd for $\mathrm{C}_{30} \mathrm{H}_{20} \mathrm{BCl}_{2} \mathrm{~F}_{2} \mathrm{~N}_{3} \mathrm{O}_{2} \mathrm{~S}[\mathrm{M}]^{-}$604.0756; found 604.0734.

Peptide Synthesis-The amide-terminated peptide sequences LARLLT and GYHWYGYTPQNVI were prepared on a 0.2 mmol scale using standard Fmoc strategy, and reacted with Fmoc-NH-PEG3-propionic acid to create the pegylated sequences: PEG3LARLLT (6) and PEG3-GYHWYGYTPQNVI (7). A cleavage cocktail of TFA (94\%), Millipore water (2.5\%), liquefied phenol (2.5\%) and Tris (1\%) was added to the resin for $3-$ $5 \mathrm{~h}$ to remove peptides from resin beads. The peptides were precipitated using cold $\left(-80^{\circ} \mathrm{C}\right)$ 
anhydrous ethyl ether $(3 \times 45 \mathrm{~mL})$ and centrifuged. The supernatant was decanted and the residue washed with cold ethyl ether. The solid was dissolved in a mixture of Millipore water (A) and acetonitrile (B), freeze-dried and lyophilized. The solvent system for purification of the peptides consisted of Millipore water and HPLC grade acetonitrile with $0.1 \%$ TFA.

Peptide 6 (3PEG-LARLLT) - This peptide was obtained as a white solid $(67.53 \mathrm{mg}$, $38 \%$ ). HPLC (90\% A for $5 \mathrm{~min}, 30 \%$ A to $10 \%$ A over $13 \mathrm{~min}, 10 \%$ A to $90 \%$ A over $2 \mathrm{~min}$ at a flow rate of $4 \mathrm{~mL} / \mathrm{min})$ and $\mathrm{t}_{\mathrm{R}}=13.95 \mathrm{~min} .{ }^{1} \mathrm{H} \mathrm{NMR}(500 \mathrm{MHz}, \mathrm{DMSO}) \delta 8.13(\mathrm{~d}, J=$ $7.4 \mathrm{~Hz}, 2 \mathrm{H}), 8.00$ (dd, $J=19.6,7.7 \mathrm{~Hz}, 2 \mathrm{H}), 7.93(\mathrm{~d}, J=8.1 \mathrm{~Hz}, 1 \mathrm{H}), 7.78(\mathrm{~s}, 2 \mathrm{H}), 7.57$ (t, $J$ $=5.4 \mathrm{~Hz}, 1 \mathrm{H}), 7.38(\mathrm{~d}, J=8.5 \mathrm{~Hz}, 1 \mathrm{H}), 7.05(\mathrm{~d}, J=20.9 \mathrm{~Hz}, 3 \mathrm{H}), 4.28(\mathrm{~m}, 5 \mathrm{H}), 4.05(\mathrm{~m}$, $3 \mathrm{H}), 3.57(\mathrm{~m}, 16 \mathrm{H}), 3.10(\mathrm{~m}, 2 \mathrm{H}), 2.98(\mathrm{dd}, J=10.5,5.2 \mathrm{~Hz}, 2 \mathrm{H}), 1.64(\mathrm{~m}, 4 \mathrm{H}), 1.49(\mathrm{~m}$, $10 \mathrm{H}), 1.20(\mathrm{~d}, J=7.0 \mathrm{~Hz}, 4 \mathrm{H}), 1.00$ (d, $J=6.2 \mathrm{~Hz}, 3 \mathrm{H}), 0.87$ (m, 18H). MS (MALDI-TOF): $\mathrm{m} / \mathrm{z}$ calcd for $\mathrm{C}_{40} \mathrm{H}_{78} \mathrm{~N}_{11} \mathrm{O}_{11}[\mathrm{M}]^{+}$888.588; found 888.542.

Peptide 7 (3PEG-GYHWYGYTPQNVI)-This peptide was obtained as a white solid (108 mg, 39\%). HPLC (90\% A for $5 \mathrm{~min}, 30 \%$ A to $10 \%$ A over 13 minutes, $10 \%$ A to $90 \%$ A over $2 \mathrm{~min}$ at a flow rate of $4 \mathrm{~mL} / \mathrm{min})$ and $\mathrm{t}_{\mathrm{R}}=12.00 \mathrm{~min} .{ }^{1} \mathrm{H} \mathrm{NMR}(500 \mathrm{MHz}, \mathrm{DMSO})$ б $13.96(\mathrm{~s}, 1 \mathrm{H}), 10.72(\mathrm{~s}, 1 \mathrm{H}), 9.12(\mathrm{~s}, 3 \mathrm{H}), 8.89(\mathrm{~s}, 1 \mathrm{H}), 8.07(\mathrm{~m}, 6 \mathrm{H}), 7.68(\mathrm{~m}, 4 \mathrm{H}), 7.40$ (s, 1H), $7.30(\mathrm{~d}, J=7.9 \mathrm{~Hz}, 1 \mathrm{H}), 7.20(\mathrm{~m}, 3 \mathrm{H}), 7.01(\mathrm{~m}, 9 \mathrm{H}), 6.75(\mathrm{~s}, 1 \mathrm{H}), 6.61(\mathrm{~m}, 5 \mathrm{H})$, $4.73(\mathrm{~m}, 8 \mathrm{H}), 4.42(\mathrm{~m}, 5 \mathrm{H}), 4.16(\mathrm{~m}, 3 \mathrm{H}), 4.08(\mathrm{~m}, 2 \mathrm{H}), 3.91(\mathrm{~m}, 3 \mathrm{H}), 3.70(\mathrm{~m}, 4 \mathrm{H}), 3.58$ (m, 16H), $2.91(\mathrm{~m}, 5 \mathrm{H}), 2.65(\mathrm{~m}, 3 \mathrm{H}), 2.37(\mathrm{~m}, 2 \mathrm{H}), 2.06(\mathrm{~m}, 7 \mathrm{H}), 1.90(\mathrm{~d}, J=15.3 \mathrm{~Hz}, 3 \mathrm{H})$, $1.74(\mathrm{~m}, 2 \mathrm{H}), 1.43(\mathrm{~m}, 2 \mathrm{H}), 1.25(\mathrm{~s}, 3 \mathrm{H}), 1.10(\mathrm{~m}, 4 \mathrm{H}), 0.84$ (m, 10H). MS (MALDI-TOF): $\mathrm{m} / \mathrm{z}$ calcd for $\mathrm{C}_{86} \mathrm{H}_{119} \mathrm{~N}_{20} \mathrm{O}_{23}[\mathrm{M}+\mathrm{H}]^{+}$1799.876; found m/z 1799.972 .

General procedure for peptide conjugation-Into a $4 \mathrm{~mL}$ vial were added the pegylated peptides ( $8.79 \mathrm{mg}$ for $\mathbf{6}$ and $17.82 \mathrm{mg}$ for $\mathbf{7}, 9.9 \mu \mathrm{mol})$ and triethylamine $(10.3 \mu \mathrm{L}$, $74 \mu \mathrm{mol})$. The mixture was stirred at room temperature for $5 \mathrm{~min}$. BODIPY 5 (3.00 $\mathrm{mg}, 4.95$ $\mu \mathrm{mol})$ was added into the vial, and the final mixture was stirred at room temperature for 30 min. TLC was used to monitor the reaction. $\mathrm{H}_{2} \mathrm{O}(0.5 \mathrm{~mL})$ was added to quench the reaction, and the solvent was removed using a lyophilizer. The residue was then subjected to HPLC $\left(\mathrm{CH}_{3} \mathrm{CN} / \mathrm{H}_{2} \mathrm{O}\right.$ as the eluents for conjugate $\mathbf{8} ; \mathrm{CH}_{3} \mathrm{CN} / \mathrm{H}_{2} \mathrm{O} / \mathrm{TFA}(0.1 \%)$ as the eluents for conjugate $\mathbf{9}$ ) to provide the desired BODIPY-peptide conjugates $\mathbf{8}$ and $\mathbf{9}$.

Conjugate 8 (BODIPY-3PEG-LARLLT-NH ${ }_{2}$ )-Yield: $5.91 \mathrm{mg}, 80 \%$. HPLC (50\% A for $5 \mathrm{~min}, 10 \%$ A to $0 \%$ A over 13 minutes, $0 \%$ A to $50 \%$ A over 2 min at a flow rate of $4 \mathrm{~mL} /$ $\min )$ and $\mathrm{t}_{\mathrm{R}}=11.00 \mathrm{~min} .{ }^{1} \mathrm{H}$ NMR $(500 \mathrm{MHz}, \mathrm{DMSO}) \delta 9.87(\mathrm{~s}, 2 \mathrm{H}), 8.16(\mathrm{~s}, 2 \mathrm{H}), 8.03(\mathrm{~s}$, $4 \mathrm{H}), 7.91(\mathrm{~d}, J=8.1 \mathrm{~Hz}, 1 \mathrm{H}), 7.72(\mathrm{~d}, J=8.7 \mathrm{~Hz}, 2 \mathrm{H}), 7.68(\mathrm{~d}, J=8.6 \mathrm{~Hz}, 2 \mathrm{H}), 7.51(\mathrm{dd}, J=$ $14.9,8.7 \mathrm{~Hz}, 4 \mathrm{H}), 7.40(\mathrm{~d}, J=7.8 \mathrm{~Hz}, 2 \mathrm{H}), 7.19(\mathrm{dd}, J=23.7,9.7 \mathrm{~Hz}, 5 \mathrm{H}), 7.05(\mathrm{~m}, 4 \mathrm{H})$, $6.48(\mathrm{~s}, 1 \mathrm{H}), 4.27(\mathrm{~m}, 5 \mathrm{H}), 4.05(\mathrm{~m}, 2 \mathrm{H}), 3.92(\mathrm{~s}, 3 \mathrm{H}), 3.82(\mathrm{~s}, 3 \mathrm{H}), 3.67(\mathrm{~s}, 2 \mathrm{H}), 3.52(\mathrm{~m}$, $14 \mathrm{H}), 3.09(\mathrm{~d}, J=6.0 \mathrm{~Hz}, 2 \mathrm{H}), 1.58(\mathrm{~m}, 4 \mathrm{H}), 1.48(\mathrm{~m}, 8 \mathrm{H}), 1.21(\mathrm{~m}, 7 \mathrm{H}), 1.00(\mathrm{~d}, J=6.3$ $\mathrm{Hz}, 3 \mathrm{H}), 0.87$ (m, 18H); ${ }^{11} \mathrm{~B}$ NMR (128 MHz, DMSO) $\delta 0.368$ (t, $\left.J=30.2 \mathrm{~Hz}\right) ; \mathrm{MS}$ (MALDI-TOF): $\mathrm{m} / \mathrm{z}$ calcd for $\mathrm{C}_{70} \mathrm{H}_{98} \mathrm{BCl}_{2} \mathrm{~F}_{2} \mathrm{~N}_{14} \mathrm{O}_{11} \mathrm{~S}$ [M] ${ }^{+} 1493.659$; found 1493.726 . 
Conjugate 9 (BODIPY-3PEG-GYHWYGYTPQNVI-NH ${ }_{2}$ )—Yield: $5.95 \mathrm{mg}, 50 \%$. HPLC (50\% A for $5 \mathrm{~min}, 10 \%$ A to $0 \%$ A over 13 minutes, $0 \%$ A to $50 \%$ A over 2 min at a flow rate of $4 \mathrm{~mL} / \mathrm{min})$ and $\mathrm{t}_{\mathrm{R}}=11.99 \mathrm{~min} .{ }^{1} \mathrm{H}$ NMR $(500 \mathrm{MHz}, \mathrm{DMSO}) \delta 13.99(\mathrm{~s}, 1 \mathrm{H})$, $10.74(\mathrm{~s}, 1 \mathrm{H}), 9.89(\mathrm{~s}, 2 \mathrm{H}), 9.15$ (s, 3H), $8.90(\mathrm{~s}, 1 \mathrm{H}), 8.09$ (m, 12H), 7.70 (dd, $J=26.4,8.5$ $\mathrm{Hz}, 5 \mathrm{H}), 7.51(\mathrm{dd}, J=14.2,8.7 \mathrm{~Hz}, 4 \mathrm{H}), 7.43(\mathrm{~s}, 1 \mathrm{H}), 7.22(\mathrm{~m}, 6 \mathrm{H}), 7.03(\mathrm{~m}, 8 \mathrm{H}), 6.79(\mathrm{~s}$, $1 \mathrm{H}), 6.62(\mathrm{~d}, J=4.2 \mathrm{~Hz}, 5 \mathrm{H}), 6.54(\mathrm{~s}, 3 \mathrm{H}), 4.58(\mathrm{dd}, J=12.0,5.6 \mathrm{~Hz}, 4 \mathrm{H}), 4.38(\mathrm{t}, J=7.0$ $\mathrm{Hz}, 5 \mathrm{H}), 4.16(\mathrm{~m}, 2 \mathrm{H}), 4.08(\mathrm{t}, J=7.8 \mathrm{~Hz}, 2 \mathrm{H}), 3.92(\mathrm{~s}, 4 \mathrm{H}), 3.81(\mathrm{~s}, 3 \mathrm{H}), 3.59(\mathrm{~m}, 16 \mathrm{H})$, $3.13(\mathrm{~m}, 3 \mathrm{H}), 2.90(\mathrm{~s}, 4 \mathrm{H}), 2.67(\mathrm{~m}, 3 \mathrm{H}), 2.37(\mathrm{~m}, 2 \mathrm{H}), 1.99(\mathrm{~m}, 11 \mathrm{H}), 1.45(\mathrm{~m}, 3 \mathrm{H}), 1.16$ $(\mathrm{m}, 14 \mathrm{H}), 0.83(\mathrm{~m}, 9 \mathrm{H}) ;{ }^{11} \mathrm{~B}$ NMR $(128 \mathrm{MHz}, \mathrm{DMSO}) \delta 0.374(\mathrm{t}, J=30.2 \mathrm{~Hz})$; MS (MALDI-TOF): $\mathrm{m} / \mathrm{z}$. calcd for $\mathrm{C}_{116} \mathrm{H}_{139} \mathrm{BCl}_{2} \mathrm{~F}_{2} \mathrm{~N}_{23} \mathrm{O}_{25} \mathrm{~S}^{+}[\mathrm{M}+\mathrm{H}]^{+} 2405.950$; found 2406.018.

\section{Spectroscopic Studies}

A Varian Cary spectrophotometer and a Perkin Elmer LS55 spectrophotometer were used to measure the UV-Visible and emission spectra at room temperature. Quartz cuvettes $(1 \mathrm{~cm}$ path length) were used for both measurements. The plots of integrated absorbance vs the corresponding solution concentrations were used to determine the extinction coefficients $(\varepsilon)$ at the maximum absorption. Different dilute BODIPY solutions with absorbance values between $0.03-0.1$ at $\lambda=550 \mathrm{~nm}$ or $580 \mathrm{~nm}$ were chosen and used for the determination of the relative fluorescence quantum yields. Crystal violet perchlorate $(0.50$ in ethanol) and methylene blue ( 0.03 in methanol) were used as the external standards. ${ }^{83}$ Relative fluorescence quantum yields $\left(\Phi_{\mathrm{f}}\right)$ were calculated using the following equation: ${ }^{91}$

$$
\Phi_{\mathrm{x}}=\Phi_{\text {std }} \times\left(\operatorname{Grad}_{\mathrm{x}} / \operatorname{Grad}_{\text {std }}\right) \times\left(\mathrm{n}_{\mathrm{x}}^{2} / \mathrm{n}_{\text {std }}^{2}\right)
$$

Where $\Phi$ refers to the fluorescence quantum yields; $\mathrm{n}$ represents the refractive indexes of the solvents used for the measurement; Grad refers to the gradient of integrated fluorescence intensity vs the corresponding absorbance; subscript $\times$ and std represent the tested samples and the external standards, respectively.

\section{Crystallography}

The crystal structure of BODIPY 5 was determined from an extremely thin plate using data collected at low temperature with MoKa radiation on a Bruker Kappa Apex-II diffractometer equipped with a Triumph curved monochromator. Refinement was by SHELX2014. Hydrogen atoms were placed in idealized positions and treated as riding. The sample crystal was a twin by two-fold rotation about the reciprocal 001 direction, and the two twin components were present in nearly equal populations. Crystal data: $\mathrm{C}_{30} \mathrm{H}_{20} \mathrm{BCl}_{2} \mathrm{~F}_{2} \mathrm{~N}_{3} \mathrm{O}_{2} \mathrm{~S}, \mathrm{MW}=606.26$, triclinic, space group $\mathrm{P}-1, \mathrm{a}=8.1751(14) \AA, \mathrm{b}=$ 12.972(2) $\AA, c=13.740(3) \AA, a=102.792(13)^{\circ}, \beta=104.575(12)^{\circ}, \gamma=92.638(11)^{\circ}, V=$ 1367.2(4) $\AA^{3}, \mathrm{Z}=2, \mathrm{~d}=1.473 \mathrm{~g} \mathrm{~cm}^{-3}, \mathrm{~T}=90 \mathrm{~K}$. The total number of reflections measured to $\theta_{\max }=23.4^{\circ}$ was 11,182 , yielding 3879 independent data, of which only 1931 were observed with $\mathrm{F}^{2}>2 \sigma\left(\mathrm{F}^{2}\right), \mathrm{R}_{\text {int }}=0.130, \mathrm{R}=0.141, \mathrm{wR}\left(\mathrm{F}^{2}\right)=0.389$ for all data and 373 refined parameters. ISOR restraints were necessary to prevent non-positive-definite ellipsoids for some C atoms. The total of 228 restraints was used. CCDC 1523511. 


\section{Surface Plasmon Resonance}

SPR was performed using Biacore X100 from GE Health Sciences. Pure recombinant protein EGFR was obtained from Leinco Technologies (St. Louis, MO). HBS-EP+ buffer and $100 \mathrm{mM}$ glycine at $\mathrm{pH} 4,4.5,5,5.5$ were purchased from GE Health Science. The extracellular domain of EGFR protein was immobilized on a CM5 sensor chip (GE Healthcare Biosciences) at a rate of $10 \mu \mathrm{L} / \mathrm{min}$ using a traditional amine coupling procedure. The carboxyl groups on the CM5 chip were activated using a solution containing $0.2 \mathrm{M} \mathrm{N}$ ethyl N-(dimethylaminopropyl) carbodiimide (EDC) and $0.05 \mathrm{M}$ N-hydroxysuccinimide (NHS) (35 $\mu \mathrm{L}$ solution, with a flow rate of $5 \mu \mathrm{L} / \mathrm{min})$. The running buffer for peptides was HBS-EP+ buffer diluted 10 times, containing 0.01 M HEPES, $0.15 \mathrm{M} \mathrm{NaCl}, 3 \mathrm{mM}$ EDTA, and $0.005 \%$ surfactant $\mathrm{P} 20$ at $\mathrm{pH} 7.5$. Peptides dissolved in buffer were used as the analytes. The running buffer for the BODIPY conjugates was HBS-EP+ buffer diluted 10 times, also containing 0.01 M HEPES, 0.15 M NaCl, 3 mM EDTA, 0.005\% surfactant P20 at pH 7.5, but brought to 4\% DMSO concentration. BODIPY 5 and conjugates 8 and 9 were dissolved in $4 \%$ DMSO buffer solutions and used as the analytes. SPR sensorgrams were obtained and the association and dissociation rates were obtained from 0 to $250 \mu \mathrm{M}$ concentrations.

\section{Cell Studies}

The human HEp2 cell line was purchased from ATCC, and maintained in a DMEM/AMEM (50:50) mixture supplemented with FBS (10\%) and Penicillin Streptomycin (1\%). All other commercially available reagents used in the cell studies were purchased from Life Technologies.

5.1 Dark Cytotoxicity-Stock solutions ( $32 \mathrm{mM}$ ) of BODIPYs $\mathbf{5 , 8}$, and $\mathbf{9}$ were prepared using $100 \%$ DMSO as the solvent. Working solutions with concentrations of $0,6.25,12.5$, 25,50 , and $100 \mu \mathrm{M}$ were prepared from the stock solutions. The HEp2 cells were exposed to the different working solutions of BODIPYs $\mathbf{5 , 8}$ and $\mathbf{9}$ up to $100 \mu \mathrm{M}$ and incubated overnight $\left(5 \% \mathrm{CO}_{2}, 37^{\circ} \mathrm{C}\right)$. The loading medium was removed, and the cells were washed with PBS solution. The medium containing 20\% CellTiter Blue (Promega) was added and the cells incubated for another $4 \mathrm{~h}$. BMG FLUOstar Optima microplate reader was used to measure the dark cytotoxicity by reading the medium fluorescence at $570 / 615 \mathrm{~nm}$. The fluorescence intensity of the untreated cells was normalized to $100 \%$.

5.2 Phototoxicity-The HEp2 cells were exposed to the different working solutions of BODIPYs 5, 8 and 9 up to $100 \mu \mathrm{M}$ and incubated overnight $\left(5 \% \mathrm{CO}_{2}, 37{ }^{\circ} \mathrm{C}\right)$. The loading medium solution was removed, and the cells were washed with PBS solution. The fresh medium was added and the cells were then exposed to the light for $20 \mathrm{~min}$. The light source has equipped with a halogen lamp (600 W), a water filter (transmits radiation 250-950 nm) and a beam turning mirror ( $200 \mathrm{~nm}$ to $30 \mu \mathrm{m}$ spectral range, Newport). The total light dose was approximately $1.5 \mathrm{~J} / \mathrm{cm}^{2}$. After exposing to light, the cells were then incubated for another $24 \mathrm{~h}$, followed by the measurement of cell viability as described above.

5.3. Time-Dependent Cellular Uptake-The HEp2 cells were exposed to $10 \mu \mathrm{M}$ concentration solutions of BODIPYs $\mathbf{5 , 8}$ and $\mathbf{9}$ for different periods of time $(0,1,2,4,8$, and $24 \mathrm{~h}$ ). The loading medium solution was removed, and the cells were washed with PBS 
solution. The cells were then solubilized by adding $0.25 \%$ Triton X-100 in PBS solution. BODIPY solutions with concentrations of $10,5,2.5,1.25,0.625$, and $0.3125 \mu \mathrm{M}$ were prepared by diluting $400 \mu \mathrm{M}$ of each compound with $0.25 \%$ Triton X-100 (Sigma-Aldrich) in PBS and used to obtain the standard curves. The concentration of the compounds was determined using a BMG FLUOstar Optima microplate reader at 570/720 nm.

5.4. Microscopy-The human HEp2 cells were incubated in a $35 \mathrm{~mm}$ tissue culture dish (CELLTREAT) and allowed to grow overnight. The cells were exposed to each compound at a concentration of $10 \mu \mathrm{M}$ and incubated for $6 \mathrm{~h}\left(5 \% \mathrm{CO}_{2}, 37^{\circ} \mathrm{C}\right)$. The following organelle trackers (Invitrogen) were added to the cells: ER Tracker Blue/White (100 nM), BODIPY FL C5 Ceramide (50 nM), MitoTracker Green (250 nM), LysoSensor Green (50 nM). The cells were incubated with each compound and trackers for half an hour, and washed with PBS solution three times before imaging. A Leica DM6B upright microscope equipped with a water immersion objective, and DAPI, GFP, and Texas Red filter cubes (Chroma Technologies) were used to acquire the images.

\section{Modeling and docking}

The 3D structures of conjugates 8 and 9 were built using InsightII (BIOVIA San Diego, CA) molecular modeling software. The BODIPY structure was obtained from the coordinates of the crystal structure of $\mathbf{5}$ described in this report. Peptides LARLLT and GYHWYGYTPQNVI were linked to BODIPY 5 via the triethylene glycol linker. The 3D structures generated were energy minimized using 100 steps of the steepest descent method, and then the conjugate gradient method in vacuum. The folded structures of the compounds were used for the docking studies.

For the EGFR receptor 3D structure, the pdb file $1 \mathrm{nql}{ }^{92}$ that represents EGFR in a closed conformation was downloaded from the protein data bank, and water and other molecules were removed from the structure file. Conjugates 8 and $\mathbf{9}$ contain a boron atom in the BODIPY core and forcefield parameters were not defined in the Autodock default parameters file. Parameters for boron can be obtained from the literature, ${ }^{93}$ however, for docking calculations the boron atom was replaced with a carbon atom, as boron atom is not calibrated in docking studies using Autodock. For conjugate $\mathbf{8}$ a grid was created around amino acids Glu71, Asn134, and Gly177 on the EGFR, and for conjugate 9 a grid was created near the EGF binding site, as reported in previous studies. ${ }^{20,25-26,93}$ Docking was performed using Autodock $4 .{ }^{90}$ The lowest energy docked structure was represented using PyMol software (Schrodinger LLC, Portland, OR).

\section{Supplementary Material}

Refer to Web version on PubMed Central for supplementary material.

\section{Acknowledgments}

This work was supported by the National Institutes of Health, grant number R01 CA179902. 


\section{ABBREVIATIONS}

$\begin{array}{ll}\text { BODIPY } & \text { boron dipyrromethene } \\ \text { EGFR } & \text { epidermal growth factor receptors } \\ \text { CAD } & \text { computer-assisted design } \\ \text { CRC } & \text { colorectal cancer } \\ \text { DMF } & \text { dimethylformamide } \\ \text { DMSO } & \text { dimethylsulfoxide } \\ \text { DSSC } & \text { dye sensitized solar cells } \\ \text { EDTA } & \text { ethylenediaminetetraacetic acid }\end{array}$

EDC N-ethyl N-(dimethylaminopropyl)

EGFR epidermal growth factor receptor

ER endoplasmic reticulum

FBS fetal bovine serum

FDA food and drug administration

HBSS Hank's balanced salt solution

HEPES 2-[4-(2-hydroxyethyl)piperazin-1-yl]ethane sulfonic acid

HPLC high performance liquid chromatography

MO molecular orbital

NHS N-hydroxysuccinimide

PBS phosphate buffered saline

PBS phosphate buffered saline

PDT photodynamic therapy

SPR surface plasmon resonance

TCCA trichloroisocyanuric acid

TDP thiocarbonyldi-2(1H)-pyridone

TEA trimethylamine

TFA trifluoroacetic acid

TLC thin layer chromatography

Tris triisopropylsilane 


\section{References}

1. Tomas A, Futter CE, Eden ER. EGF receptor trafficking: consequences for signaling and cancer. Trends Cell Biol. 2014; 24:26-34. [PubMed: 24295852]

2. Yewale C, Baradia D, Vhora I, Patil S, Misra A. Epidermal growth factor receptor targeting in cancer: A review of trends and strategies. Biomaterials. 2013; 34:8690-8707. [PubMed: 23953842]

3. Hynes NE, Lane HA. ERBB receptors and cancer: the complexity of targeted inhibitors. Nat Rev Cancer. 2005; 5:341-354. [PubMed: 15864276]

4. Burgess AW, Cho HS, Eigenbrot C, Ferguson KM, Garrett TPJ, Leahy DJ, Lemmon MA, Sliwkowski MX, Ward CW, Yokoyama S. An Open-and-Shut Case? Recent Insights into the Activation of EGF/ErbB Receptors. Mol Cell. 2003; 12:541-552. [PubMed: 14527402]

5. Rocha-Lima CM, Soares PH, Raez LESR. EGFR targeting of solid tumors. Cancer Control. 2007; 14:295-304. [PubMed: 17615536]

6. Roengvoraphoj M, Tsongalis GJ, Dragnev KH, Rigas JR. Epidermal growth factor receptor tyrosine kinase inhibitors as initial therapy for non-small cell lung cancer: Focus on epidermal growth factor receptor mutation testing and mutation-positive patients. Cancer Treat Rev. 2013; 39:839-850. [PubMed: 23768755]

7. Paez JG, Jänne PA, Lee JC, Tracy S, Greulich H, Gabriel S, Herman P, Kaye FJ, Lindeman N, Boggon TJ, et al. EGFR Mutations in Lung Cancer: Correlation with Clinical Response to Gefitinib Therapy. Science. 2004; 304:1497-1500. [PubMed: 15118125]

8. Dougherty U, Sehdev A, Cerda S, Mustafi R, Little N, Yuan W, Jagadeeswaran S, Chumsangsri A, Delgado J, Tretiakova M, et al. Epidermal Growth Factor Receptor Controls Flat Dysplastic Aberrant Crypt Foci Development and Colon Cancer Progression in the Rat Azoxymethane Model. Clin Cancer Res. 2008; 14:2253-2262. [PubMed: 18413814]

9. Key Statistics for Colorectal Cancer. American Cancer Society; 2016. http://www.cancer.org/cancer/ colonandrectumcancer/detailedguide/colorectal-cancer-key-statistics

10. Siegel RL, Fedewa SA, Anderson WF, Miller KD, Ma J, Rosenberg PS, Jemal A. Colorectal Cancer Incidence Patterns in the United States, 1974-2013. JNCI J Natl Cancer Inst. 2017; 109:djw322-djw322.

11. Kiesslich R, Goetz M, Vieth M, Galle PR, Neurath MF. Technology Insight: confocal laser endoscopy for in vivo diagnosis of colorectal cancer. Nat Clin Prac Oncol. 2007; 4:480-490.

12. Hudson R, Boyle RW. Strategies for selective delivery of photodynamic sensitisers to biological targets. J Porphyrins Phthalocyanines. 2004; 08:954-975.

13. Bhirde AA, Patel V, Gavard J, Zhang G, Sousa AA, Masedunskas A, Leapman RD, Weigert R, Gutkind JS, Rusling JF. Targeted Killing of Cancer Cells in Vivo and in Vitro with EGF-Directed Carbon Nanotube-Based Drug Delivery. ACS Nano. 2009; 3:307-316. [PubMed: 19236065]

14. Patra CR, Bhattacharya R, Wang E, Katarya A, Lau JS, Dutta S, Muders M, Wang S, Buhrow SA, Safgren SL, et al. Targeted Delivery of Gemcitabine to Pancreatic Adenocarcinoma Using Cetuximab as a Targeting Agent. Cancer Res. 2008; 68:1970-1978. [PubMed: 18339879]

15. Saki M, Toulany M, Sihver W, Zenker M, Heldt JM, Mosch B, Pietzsch HJ, Baumann M, Steinbach J, Rodemann HP. Cellular and molecular properties of 90Y-labeled cetuximab in combination with radiotherapy on human tumor cells in vitro. Strahlentherapie und Onkologie. 2012; 188:823-832. [PubMed: 22875052]

16. Leonidova A, Foerster C, Zarschler K, Schubert M, Pietzsch HJ, Steinbach J, Bergmann R, Metzler-Nolte N, Stephan H, Gasser G. In vivo demonstration of an active tumor pretargeting approach with peptide nucleic acid bioconjugates as complementary system. Chem Sci. 2015; 6:5601-5616.

17. Yang L, Mao H, Wang YA, Cao Z, Peng X, Wang X, Duan H, Ni C, Yuan Q, Adams G, et al. Single Chain Epidermal Growth Factor Receptor Antibody Conjugated Nanoparticles for in vivo Tumor Targeting and Imaging. Small. 2009; 5:235-243. [PubMed: 19089838]

18. Sexton K, Tichauer K, Samkoe KS, Gunn J, Hoopes PJ, Pogue BW. Fluorescent Affibody Peptide Penetration in Glioma Margin Is Superior to Full Antibody. PLoS ONE. 2013; 8:e60390.

[PubMed: 23593208] 
19. Nordberg E, Friedman M, Göstring L, Adams GP, Brismar H, Nilsson FY, Ståhl S, Glimelius B, Carlsson J. Cellular studies of binding, internalization and retention of a radiolabeled EGFRbinding affibody molecule. Nucl Med Biol. 2007; 34:609-618. [PubMed: 17707800]

20. Li Z, Zhao R, Wu X, Sun Y, Yao M, Li J, Xu Y, Gu J. Identification and characterization of a novel peptide ligand of epidermal growth factor receptor for targeted delivery of therapeutics. FASEB J. 2005; 19:1978-1985. [PubMed: 16319141]

21. Bell A, Wang ZJ, Arbabi-Ghahroudi M, Chang TA, Durocher Y, Trojahn U, Baardsnes J, Jaramillo ML, Li S, Baral TN, et al. Differential tumor-targeting abilities of three single-domain antibody formats. Cancer Lett. 2010; 289:81-90. [PubMed: 19716651]

22. Mickler FM, Möckl L, Ruthardt N, Ogris M, Wagner E, Bräuchle C. Tuning Nanoparticle Uptake: Live-Cell Imaging Reveals Two Distinct Endocytosis Mechanisms Mediated by Natural and Artificial EGFR Targeting Ligand. Nano Lett. 2012; 12:3417-3423. [PubMed: 22632479]

23. Chariou PL, Lee KL, Wen AM, Gulati NM, Stewart PL, Steinmetz NF. Detection and Imaging of Aggressive Cancer Cells Using an Epidermal Growth Factor Receptor (EGFR)-Targeted Filamentous Plant Virus-Based Nanoparticle. Bioconjugate Chem. 2015; 26:262-269.

24. Zarschler K, Prapainop K, Mahon E, Rocks L, Bramini M, Kelly PM, Stephan H, Dawson KA. Diagnostic nanoparticle targeting of the EGF-receptor in complex biological conditions using single-domain antibodies. Nanoscale. 2014; 6:6046-6056. [PubMed: 24777583]

25. Song S, Liu D, Peng J, Deng H, Guo Y, Xu LX, Miller AD, Xu Y. Novel peptide ligand directs liposomes toward EGF-R high-expressing cancer cells in vitro and in vivo. FASEB J. 2009; 23:1396-1404. [PubMed: 19124558]

26. Ongarora BG, Fontenot KR, Hu X, Sehgal I, Satyanarayana-Jois SD, Vicente MGH. Phthalocyanine-Peptide Conjugates for Epidermal Growth Factor Receptor Targeting. J Med Chem. 2012; 55:3725-3738. [PubMed: 22468711]

27. Song S, Liu D, Peng J, Sun Y, Li Z, Gu JR, Xu Y. Peptide ligand-mediated liposome distribution and targeting to EGFR expressing tumor in vivo. Int J Pharm. 2008; 363:155-161. [PubMed: 18692120]

28. Bröring M, Köhler S, Kleeberg C. Norcorrole: Observation of the Smallest Porphyrin Variant with a N4 Core. Angew Chem Int Ed. 2008; 47:5658-5660.

29. Viehweger K, Barbaro L, García KP, Joshi T, Geipel G, Steinbach J, Stephan H, Spiccia L, Graham B. EGF Receptor-Targeting Peptide Conjugate Incorporating a Near-IR Fluorescent Dye and a Novel 1,4,7-Triazacyclononane-Based 64Cu(II) Chelator Assembled via Click Chemistry. Bioconjugate Chem. 2014; 25:1011-1022.

30. Banappagari S, McCall A, Fontenot K, Vicente MGH, Gujar A, Satyanarayanajois S. Design, synthesis and characterization of peptidomimetic conjugate of BODIPY targeting HER2 protein extracellular domain. Eur J Med Chem. 2013; 65:60-69. [PubMed: 23688700]

31. Ge Y, O'Shea DF. Azadipyrromethenes: from traditional dye chemistry to leading edge applications. Chem Soc Rev. 2016; 45:3846-3864. [PubMed: 27181703]

32. Lakshmi V, Rajeswara Rao M, Ravikanth M. Halogenated boron-dipyrromethenes: synthesis, properties and applications. Org Biomol Chem. 2015; 13:2501-2517. [PubMed: 25594728]

33. Loudet A, Burgess K. BODIPY Dyes and Their Derivatives: Syntheses and Spectroscopic Properties. Chem Rev. 2007; 107:4891-4932. [PubMed: 17924696]

34. Lu H, Mack J, Yang Y, Shen Z. Structural modification strategies for the rational design of red/NIR region BODIPYs. Chem Soc Rev. 2014; 43:4778-4823. [PubMed: 24733589]

35. Ulrich G, Ziessel R, Harriman A. The Chemistry of Fluorescent Bodipy Dyes: Versatility Unsurpassed. Angew Chem Int Ed. 2008; 47:1184-1201.

36. Niu LY, Guan YS, Chen YZ, Wu LZ, Tung CH, Yang QZ. BODIPY-Based Ratiometric Fluorescent Sensor for Highly Selective Detection of Glutathione over Cysteine and Homocysteine. J Am Chem Soc. 2012; 134:18928-18931. [PubMed: 23121092]

37. Boens N, Leen V, Dehaen W. Fluorescent indicators based on BODIPY. Chem Soc Rev. 2012; 41:1130-1172. [PubMed: 21796324]

38. Kowada T, Maeda H, Kikuchi K. BODIPY-based probes for the fluorescence imaging of biomolecules in living cells. Chem Soc Rev. 2015; 44:4953-4972. [PubMed: 25801415] 
39. Ni Y, Wu J. Far-red and near infrared BODIPY dyes: synthesis and applications for fluorescent $\mathrm{pH}$ probes and bio-imaging. Org Biomol Chem. 2014; 12:3774-3791. [PubMed: 24781214]

40. Ziessel R, Ulrich G, Harriman A. The chemistry of Bodipy: A new El Dorado for fluorescence tools. New J Chem. 2007; 31:496-501.

41. Yogo T, Urano Y, Ishitsuka Y, Maniwa F, Nagano T. Highly Efficient and Photostable Photosensitizer Based on BODIPY Chromophore. J Am Chem Soc. 2005; 127:12162-12163. [PubMed: 16131160]

42. Umezawa K, Nakamura Y, Makino H, Citterio D, Suzuki K. Bright, Color-Tunable Fluorescent Dyes in the Visible-Near-Infrared Region. J Am Chem Soc. 2008; 130:1550-1551. [PubMed: 18193873]

43. Gibbs JH, Robins LT, Zhou Z, Bobadova-Parvanova P, Cottam M, McCandless GT, Fronczek FR, Vicente MGH. Spectroscopic, computational modeling and cytotoxicity of a series of meso-phenyl and meso-thienyl-BODIPYs. Biorg Med Chem. 2013; 21:5770-5781.

44. Kamkaew A, Burgess K. Double-Targeting Using a TrkC Ligand Conjugated to Dipyrrometheneboron Difluoride (BODIPY) Based Photodynamic Therapy (PDT) Agent. J Med Chem. 2013; 56:7608-7614. [PubMed: 24063347]

45. Kamkaew A, Lim SH, Lee HB, Kiew LV, Chung LY, Burgess K. BODIPY dyes in photodynamic therapy. Chem Soc Rev. 2013; 42:77-88. [PubMed: 23014776]

46. Gibbs JH, Zhou Z, Kessel D, Fronczek FR, Pakhomova S, Vicente MGH. Synthesis, spectroscopic, and in vitro investigations of 2,6-diiodo-BODIPYs with PDT and bioimaging applications. J Photochem Photobiol B: Biol. 2015; 145:35-47.

47. Xuan S, Zhao N, Zhou Z, Fronczek FR, Vicente MGH. Synthesis and in Vitro Studies of a Series of Carborane-Containing Boron Dipyrromethenes (BODIPYs). J Med Chem. 2016; 59:2109-2117. [PubMed: 26849474]

48. Gibbs JH, Wang H, Bhupathiraju NVSDK, Fronczek FR, Smith KM, Vicente MGH. Synthesis and properties of a series of carboranyl-BODIPYs. J Organomet Chem. 2015; 798(Part 1):209-213. [PubMed: 26688595]

49. Ekmekci Z, Yilmaz MD, Akkaya EU. A Monostyryl-boradiazaindacene (BODIPY) Derivative as Colorimetric and Fluorescent Probe for Cyanide Ions. Org Lett. 2008; 10:461-464. [PubMed: 18181636]

50. Kolemen S, Bozdemir OA, Cakmak Y, Barin G, Erten-Ela S, Marszalek M, Yum JH, Zakeeruddin SM, Nazeeruddin MK, Gratzel M, Akkaya EU. Optimization of distyryl-Bodipy chromophores for efficient panchromatic sensitization in dye sensitized solar cells. Chem Sci. 2011; 2:949-954.

51. Bonnier C, Machin DD, Abdi O, Koivisto BD. Manipulating non-innocent [small pi]-spacers: the challenges of using 2,6-disubstituted BODIPY cores within donor-acceptor light-harvesting motifs. Org Biomol Chem. 2013; 11:3756-3760. [PubMed: 23629157]

52. Hansen AM, Sewell AL, Pedersen RH, Long DL, Gadegaard N, Marquez R. Tunable BODIPY derivatives amenable to 'click' and peptide chemistry. Tetrahedron. 2013; 69:8527-8533.

53. Verwilst P, David CC, Leen V, Hofkens J, de Witte PAM, De Borggraeve WM. Synthesis and in vitro evaluation of a PDT active BODIPY-NLS conjugate. Bioorg Med Chem Lett. 2013; 23:3204-3207. [PubMed: 23639541]

54. Maindron N, Ipuy M, Bernhard C, Lhenry D, Moreau M, Carme S, Oudot A, Collin B, Vrigneaud JM, Provent P, et al. Near-Infrared-Emitting BODIPY-trisDOTA111In as a Monomolecular Multifunctional Imaging Probe: From Synthesis to In Vivo Investigations. Chem Eur J. 2016; 22:12670-12674. [PubMed: 27410465]

55. Witte MD, Descals CV, de Lavoir SVP, Florea BI, van der Marel GA, Overkleeft HS. BodipyVAD-Fmk, a useful tool to study yeast peptide N-glycanase activity. Org Biomol Chem. 2007; 5:3690-3697. [PubMed: 17971999]

56. de la Torre BG, Hornillos V, Luque-Ortega JR, Abengózar MA, Amat-Guerri F, Ulises Acuña A, Rivas L, Andreu D. A BODIPY-embedding miltefosine analog linked to cell-penetrating Tat(48$60)$ peptide favors intracellular delivery and visualization of the antiparasitic drug. Amino Acids. 2014; 46:1047-1058. [PubMed: 24445871] 
57. Kondo N, Temma T, Deguchi J, Sano K, Ono M, Saji H. Development of PEGylated peptide probes conjugated with 18F-labeled BODIPY for PET/optical imaging of MT1-MMP activity. J Controlled Release. 2015; 220(Part A):476-483.

58. Wang D, Fan J, Gao X, Wang B, Sun S, Peng X. Carboxyl BODIPY Dyes from Bicarboxylic Anhydrides: One-Pot Preparation, Spectral Properties, Photostability, and Biolabeling. J Org Chem. 2009; 74:7675-7683. [PubMed: 19772337]

59. Mendive-Tapia L, Zhao C, Akram AR, Preciado S, Albericio F, Lee M, Serrels A, Kielland N, Read ND, Lavilla R, et al. Spacer-free BODIPY fluorogens in antimicrobial peptides for direct imaging of fungal infection in human tissue. Nat Commun. 2016; 7:10940. [PubMed: 26956772]

60. Karlsson I, Samuelsson K, Ponting DJ, Törnqvist M, Ilag LL, Nilsson U. Peptide Reactivity of Isothiocyanates - Implications for Skin Allergy. Sci Rep. 2016; 6:21203. [PubMed: 26883070]

61. Wang D, Fang S, Wohlhueter RM. N-Terminal Derivatization of Peptides with Isothiocyanate Analogues Promoting Edman-Type Cleavage and Enhancing Sensitivity in Electrospray Ionization Tandem Mass Spectrometry Analysis. Anal Chem. 2009; 81:1893-1900. [PubMed: 19199379]

62. Sureshbabu VV, Naik SA, Hemantha HP, Narendra N, Das U, Guru Row TN. N-UrethaneProtected Amino Alkyl Isothiocyanates: Synthesis, Isolation, Characterization, and Application to the Synthesis of Thioureidopeptides. J Org Chem. 2009; 74:5260-5266. [PubMed: 19537728]

63. Perreault A, Richter S, Bergman C, Wuest M, Wuest F. Targeting Phosphatidylserine with a 64CuLabeled Peptide for Molecular Imaging of Apoptosis. Mol Pharm. 2016; 13:3564-3577. [PubMed: 27608290]

64. Poty S, Gourni E, Désogère P, Boschetti F, Goze C, Maecke HR, Denat F. AMD3100: A Versatile Platform for CXCR4 Targeting 68Ga-Based Radiopharmaceuticals. Bioconjugate Chem. 2016; 27:752-761.

65. Sutton JM, Clarke OJ, Fernandez N, Boyle RW. Porphyrin, Chlorin, and Bacteriochlorin Isothiocyanates: Useful Reagents for the Synthesis of Photoactive Bioconjugates. Bioconjugate Chem. 2002; 13:249-263.

66. Hudson R, Carcenac M, Smith K, Madden L, Clarke OJ, Pelegrin A, Greenman J, Boyle RW. The development and characterisation of porphyrin isothiocyanate-monoclonal antibody conjugates for photoimmunotherapy. Br J Cancer. 2005; 92:1442-1449. [PubMed: 15812551]

67. Brizet B, Goncalves V, Bernhard C, Harvey PD, Denat F, Goze C. DMAP-BODIPY Alkynes: A Convenient Tool for Labeling Biomolecules for Bimodal PET-Optical Imaging. Chem Eur J. 2014; 20:12933-12944. [PubMed: 25145483]

68. Lhenry D, Larrouy M, Bernhard C, Goncalves V, Raguin O, Provent P, Moreau M, Collin B, Oudot A, Vrigneaud JM, et al. BODIPY: A Highly Versatile Platform for the Design of Bimodal Imaging Probes. Chem Eur J. 2015; 21:13091-13099. [PubMed: 26206262]

69. Dumont Y, Gaudreau P, Mazzuferi M, Langlois D, Chabot JG, Fournier A, Simonato M, Quirion R. BODIPY®-conjugated neuropeptide Y ligands: new fluorescent tools to tag Y1, Y2, Y4 and Y5 receptor subtypes. Br J Pharmacol. 2005; 146:1069-1081. [PubMed: 16231000]

70. Liu L, Fu L, Jing T, Ruan Z, Yan L. pH-Triggered Polypeptides Nanoparticles for Efficient BODIPY Imaging-Guided Near Infrared Photodynamic Therapy. ACS Appl Mater Interfaces. 2016; 8:8980-8990. [PubMed: 27020730]

71. Malatesti N, Hudson R, Smith K, Savoie H, Rix K, Welham K, Boyle RW. Isothiocyanato Boron Dipyrromethenes-The First BODIPY Analogues of Fluorescein Isothiocyanate. Photochem Photobiol. 2006; 82:746-749. [PubMed: 16789844]

72. Boas U, Gertz H, Christensen JB, Heegaard PMH. Facile synthesis of aliphatic isothiocyanates and thioureas on solid phase using peptide coupling reagents. Tetrahedron Lett. 2004; 45:269-272.

73. Wang H, Fronczek FR, Vicente MGH, Smith KM. Functionalization of 3,5,8-Trichlorinated BODIPY Dyes. J Org Chem. 2014; 79:10342-10352. [PubMed: 25268574]

74. Zhao N, Vicente MGH, Fronczek FR, Smith KM. Synthesis of 3,8-Dichloro-6-ethyl-1,2,5,7tetramethyl-BODIPY from an Asymmetric Dipyrroketone and Reactivity Studies at the 3,5,8Positions. Chem Eur J. 2015; 21:6181-6192. [PubMed: 25761150]

75. Zhao N, Xuan S, Byrd B, Fronczek FR, Smith KM, Vicente MGH. Synthesis and regioselective functionalization of perhalogenated BODIPYs. Org Biomol Chem. 2016; 14:6184-6188. [PubMed: 27251595] 
76. Zhao N, Xuan S, Fronczek FR, Smith KM, Vicente MGH. Stepwise Polychlorination of 8-ChloroBODIPY and Regioselective Functionalization of 2,3,5,6,8-Pentachloro-BODIPY. J Org Chem. 2015; 80:8377-8383. [PubMed: 26186141]

77. Xuan S, Zhao N, Ke X, Zhou Z, Fronczek FR, Kadish KM, Smith KM, Vicente MGH. Synthesis and Spectroscopic Investigation of a Series of Push-Pull Boron Dipyrromethenes (BODIPYs). J Org Chem. 2017; 82:2545-2557. [PubMed: 28150499]

78. Li L, Han J, Nguyen B, Burgess K. Syntheses and Spectral Properties of Functionalized, WaterSoluble BODIPY Derivatives. J Org Chem. 2008; 73:1963-1970. [PubMed: 18271598]

79. Fontenot KR, Ongarora BG, LeBlanc LE, Zhou Z, Jois SD, Vicente MGH. Targeting of the epidermal growth factor receptor with mesoporphyrin IX-peptide conjugates. J Porphyrins Phthalocyanines. 2016; 20:352-366.

80. Hermanson, GT. Bioconjugate techniques. Academic press; 2013.

81. Sibrian-Vazquez M, Jensen TJ, Hammer RP, Vicente MGH. Peptide-Mediated Cell Transport of Water Soluble Porphyrin Conjugates. J Med Chem. 2006; 49:1364-1372. [PubMed: 16480271]

82. Sibrian-Vazquez M, Ortiz J, Nesterova IV, Fernández-Lázaro F, Sastre-Santos A, Soper SA, Vicente MGH. Synthesis and Properties of Cell-Targeted Zn(II)-Phthalocyanine-Peptide Conjugates. Bioconjugate Chem. 2007; 18:410-420.

83. Olmsted J. Calorimetric determinations of absolute fluorescence quantum yields. J Phys Chem. 1979; 83:2581-2584.

84. Ntziachristos V. Going deeper than microscopy: the optical imaging frontier in biology. Nat Meth. 2010; 7:603-614.

85. Komolov, KE., Koch, K-W. Application of Surface Plasmon Resonance Spectroscopy to Study GProtein Coupled Receptor Signalling. In: Mol, NJ., Fischer, MJE., editors. Surface Plasmon Resonance: Methods and Protocols. Humana Press; Totowa, NJ: 2010. p. 249-260.

86. Wilson WD. Analyzing Biomolecular Interactions. Science. 2002; 295:2103-2105. [PubMed: 11896282]

87. Zhang S, Li Y, He X, Dong S, Huang Y, Li X, Li Y, Jin C, Zhang Y, Wang Y. Photothermolysis mediated by gold nanorods modified with EGFR monoclonal antibody induces Hep-2 cells apoptosis in vitro and in vivo. Int J Nanomedicine. 2014; 9:1931-1946. [PubMed: 24790435]

88. Sibrian-Vazquez M, Jensen TJ, Vicente MGH. Influence of the number and distribution of NLS peptides on the photosensitizing activity of multimeric porphyrin-NLS. Org Biomol Chem. 2010; 8:1160-1172. [PubMed: 20165809]

89. Uppal T, Bhupathiraju NVSDK, Vicente MGH. Synthesis and cellular properties of Near-IR BODIPY-PEG and carbohydrate conjugates. Tetrahedron. 2013; 69:4687-4693.

90. Morris GM, Huey R, Lindstrom W, Sanner MF, Belew RK, Goodsell DS, Olson AJ. AutoDock4 and AutoDockTools4: Automated docking with selective receptor flexibility. J Comput Chem. 2009; 30:2785-2791. [PubMed: 19399780]

91. Gorka AP, Nani RR, Zhu J, Mackem S, Schnermann MJ. A Near-IR Uncaging Strategy Based on Cyanine Photochemistry. J Am Chem Soc. 2014; 136:14153-14159. [PubMed: 25211609]

92. Ferguson KM, Berger MB, Mendrola JM, Cho HS, Leahy DJ, Lemmon MA. EGF Activates Its Receptor by Removing Interactions that Autoinhibit Ectodomain Dimerization. Mol Cell. 2003; 11:507-517. [PubMed: 12620237]

93. Tafi A, Agamennone M, Tortorella P, Alcaro S, Gallina C, Botta M. AMBER force field implementation of the boronate function to simulate the inhibition of $\beta$-lactamases by alkyl and aryl boronic acids. Eur J Med Chem. 2005; 40:1134-1142. [PubMed: 16153747] 

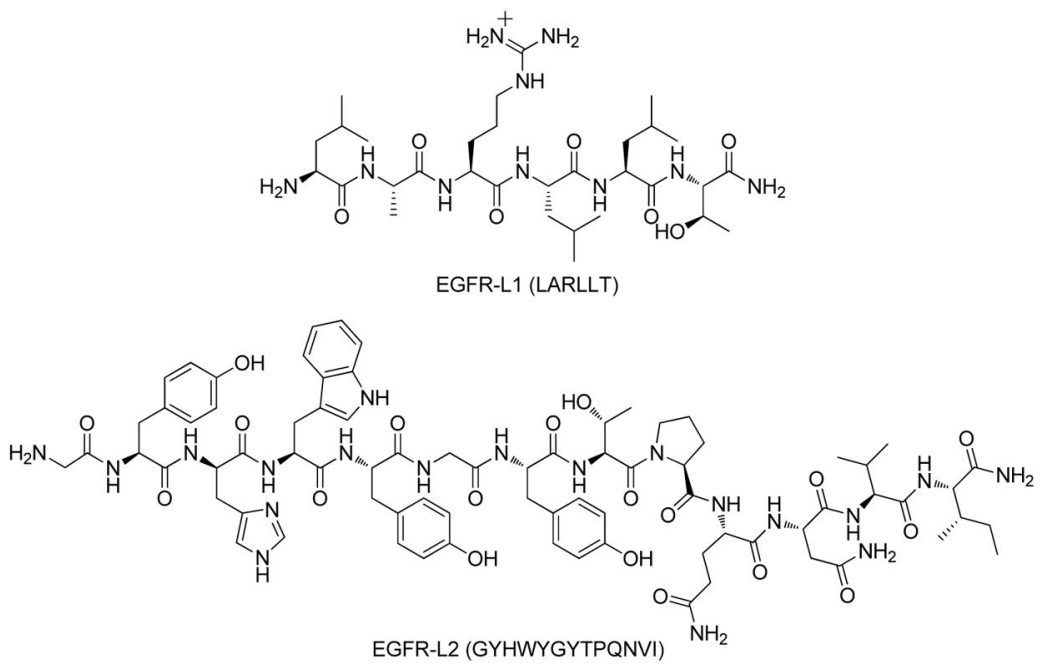

Figure 1.

Structures of EGFR-L1 and EGFR-L2 


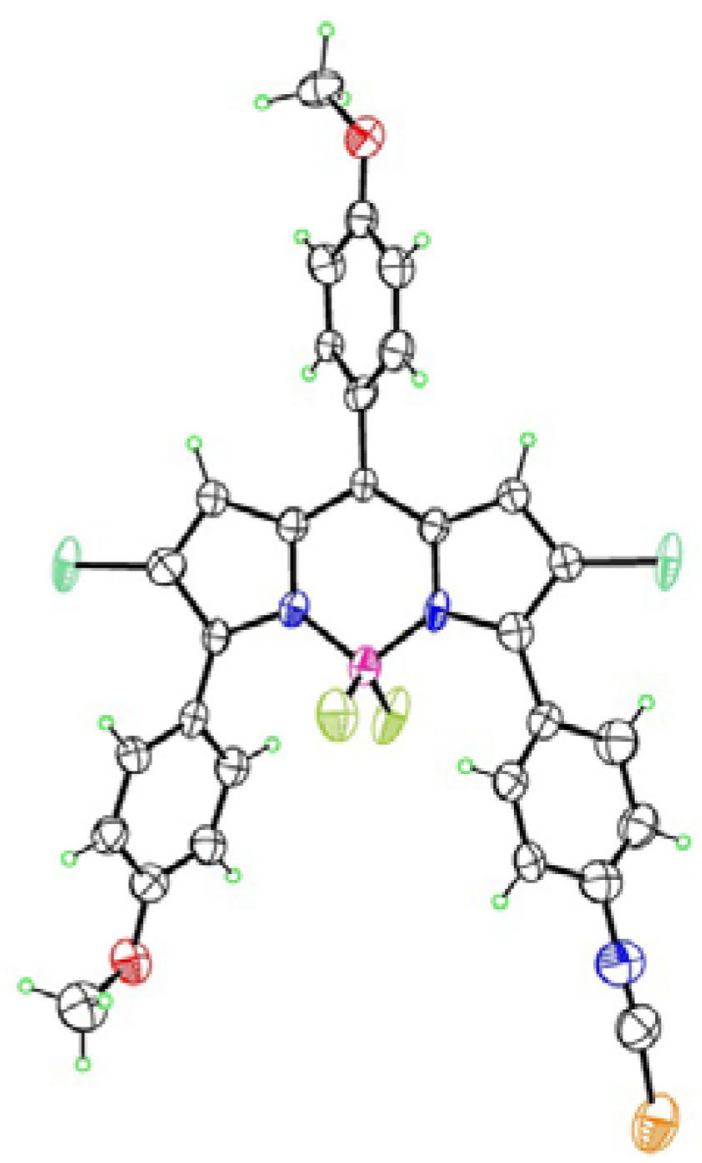

Figure 2.

X-ray structure of BODIPY 5. 

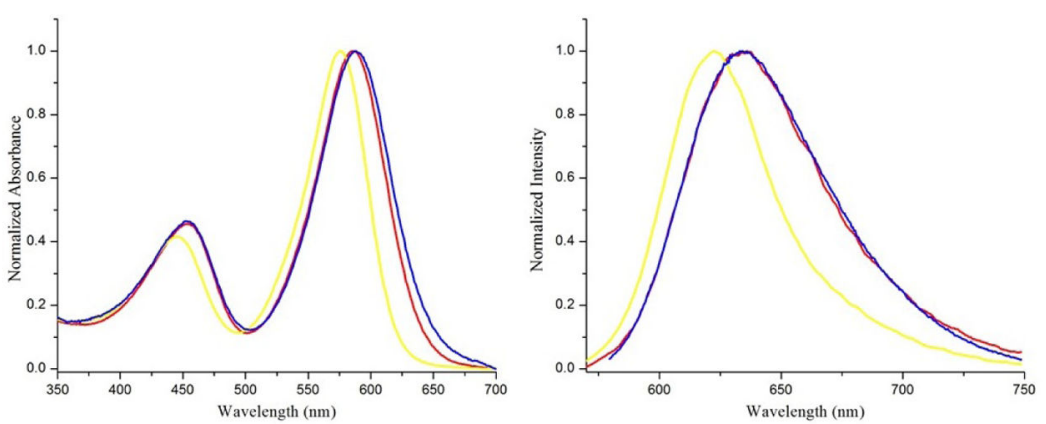

Figure 3.

Normalized UV-Vis and fluorescence emission spectra of BODIPYs 5 (yellow), BODIPYpeptide conjugate 8 (blue), and BODIPY-peptide conjugate 9 (red) in DMSO at room temperature. 

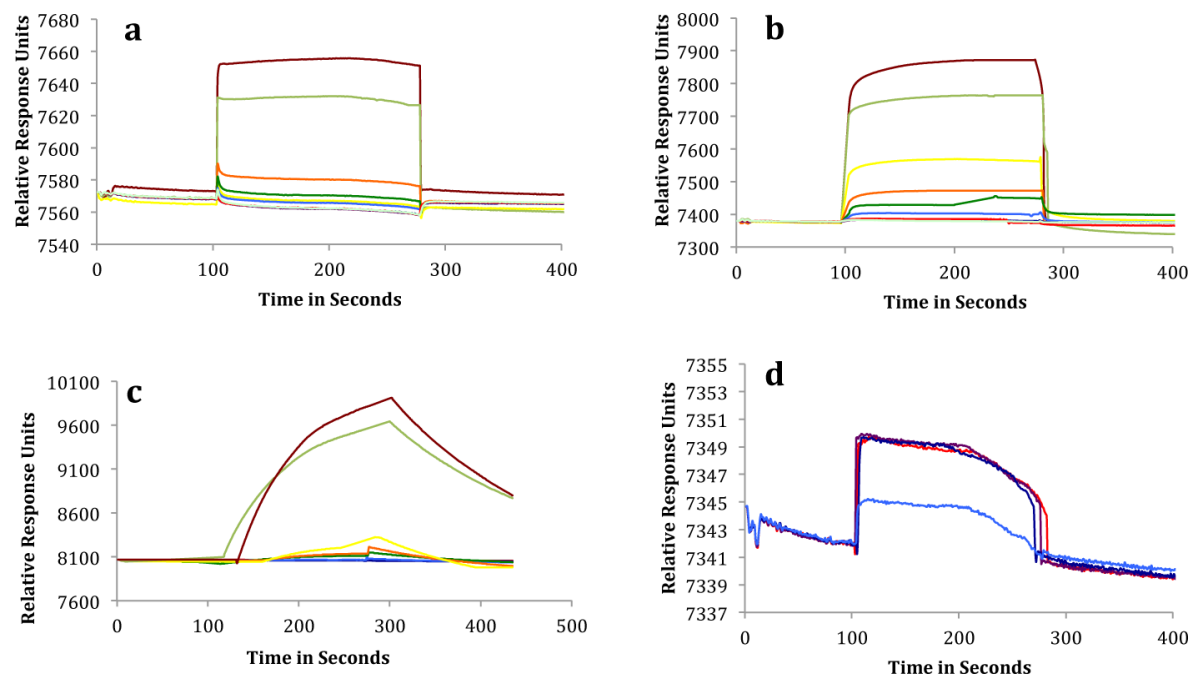

Figure 4.

SPR sensograms for peptides 6 (a) and 7 (b), and conjugates 8 (c) and 9 (d) binding to EGFR, at concentrations up to $250 \mu \mathrm{M}$ (burgundy); $200 \mu \mathrm{M}$ (lime), $100 \mu \mathrm{M}$ (yellow), $50 \mu \mathrm{M}$ (orange), $25 \mu \mathrm{M}$ (green), $10 \mu \mathrm{M}$ (royal blue), $1 \mu \mathrm{M}$ (navy blue), $0.5 \mu \mathrm{M}$ (purple), and bank (mint). 


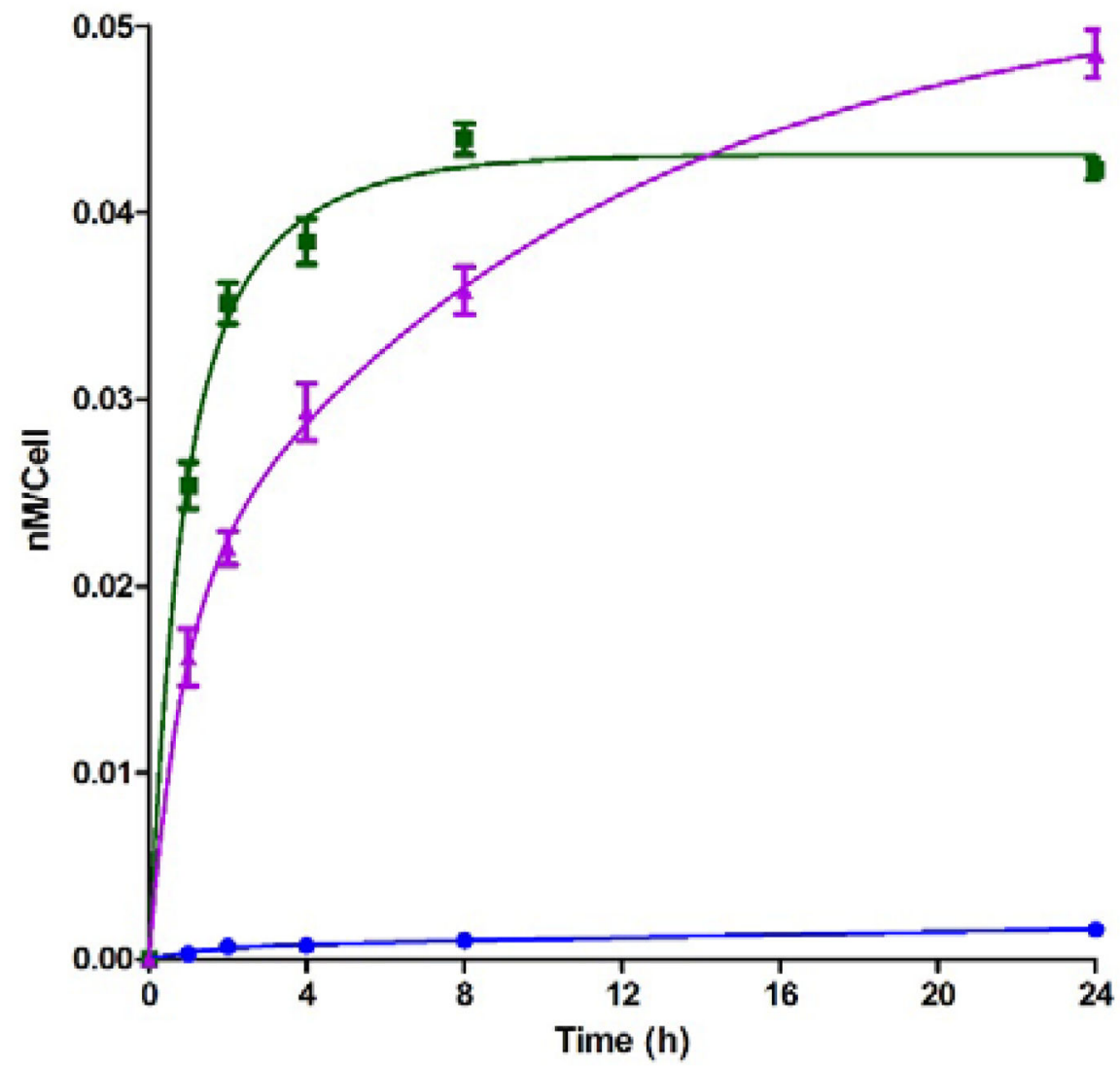

Figure 5.

Time-dependent cellular uptake of BODIPYs 5 (blue), 8 (green) and $\mathbf{9}$ (purple) at $10 \mu \mathrm{M}$ in human HEp2 cells. 


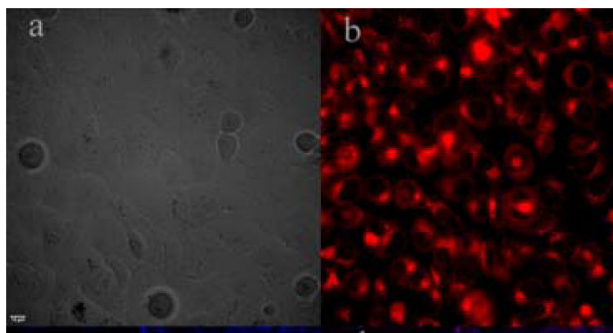

$$
\mathrm{c}
$$

d

Figure 6.

Subcellular fluorescence of conjugate 8 in HEp2 cells at $10 \mu \mathrm{M}$ for $6 \mathrm{~h}$. (a) Phase contrast; (b) overlay of $\mathbf{8}$ fluorescence and phase contrast; (c) ER tracker Blue/White fluorescence; (d) overlay of $\mathbf{8}$ fluorescence and ER Tracker; (e) BODIPY Ceramide; (f) overlay of $\mathbf{8}$ fluorescence and BODIPY ceramide; (g) MitoTracker Green fluorescence; (h) overlay of 8 fluorescence and MitoTracker Green; (i) LysoSensor Green fluorescence; (j) overlay of $\mathbf{8}$ fluorescence and LysoSensor Green. Scale bar: $10 \mu \mathrm{m}$. 


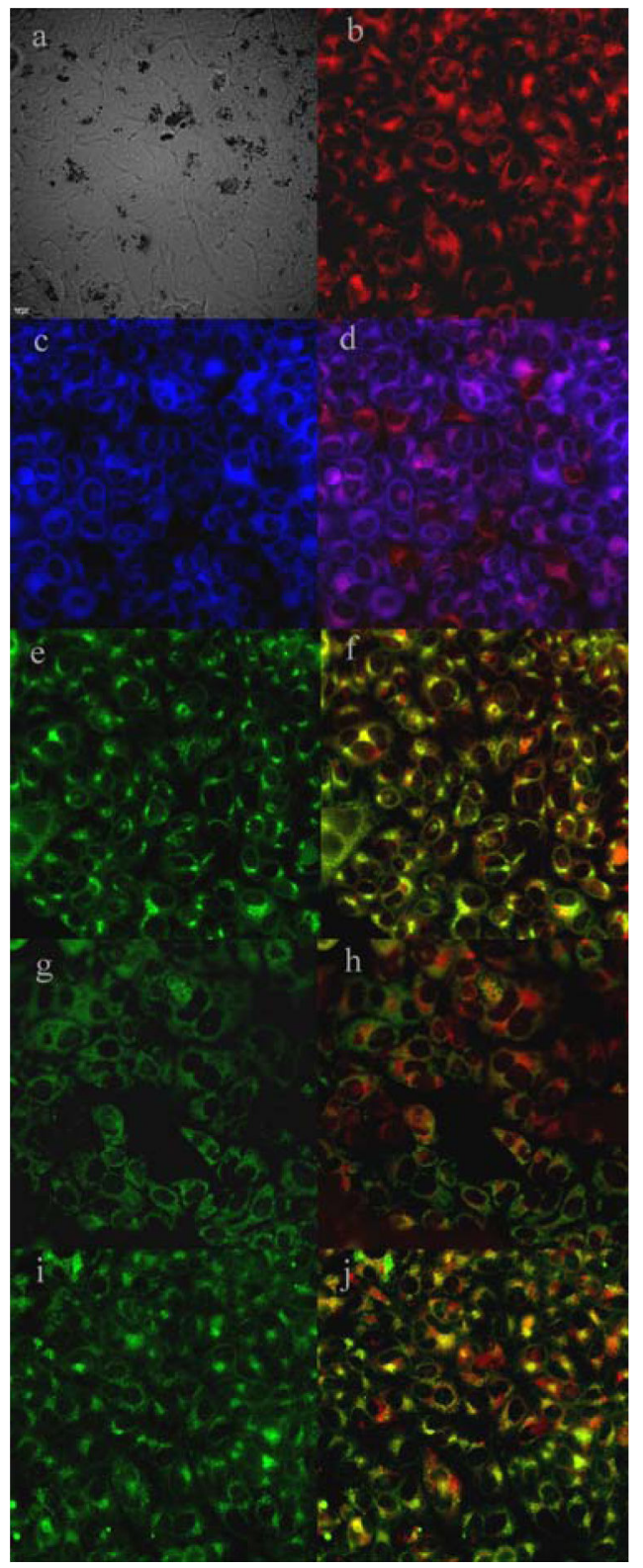

Figure 7.

Subcellular fluorescence of conjugate 9 in HEp2 cells at $10 \mu \mathrm{M}$ for $6 \mathrm{~h}$. (a) Phase contrast; (b) overlay of 9 fluorescence and phase contrast; (c) ER tracker Blue/White fluorescence; (d) overlay of 9 fluorescence and ER Tracker; (e) BODIPY Ceramide; (f) overlay of 9 fluorescence and BODIPY ceramide; (g) MitoTracker Green fluorescence; (h) overlay of 9 fluorescence and MitoTracker Green; (i) LysoSensor Green fluorescence; (j) overlay of 9 fluorescence and LysoSensor Green. Scale bar: $10 \mu \mathrm{m}$. 

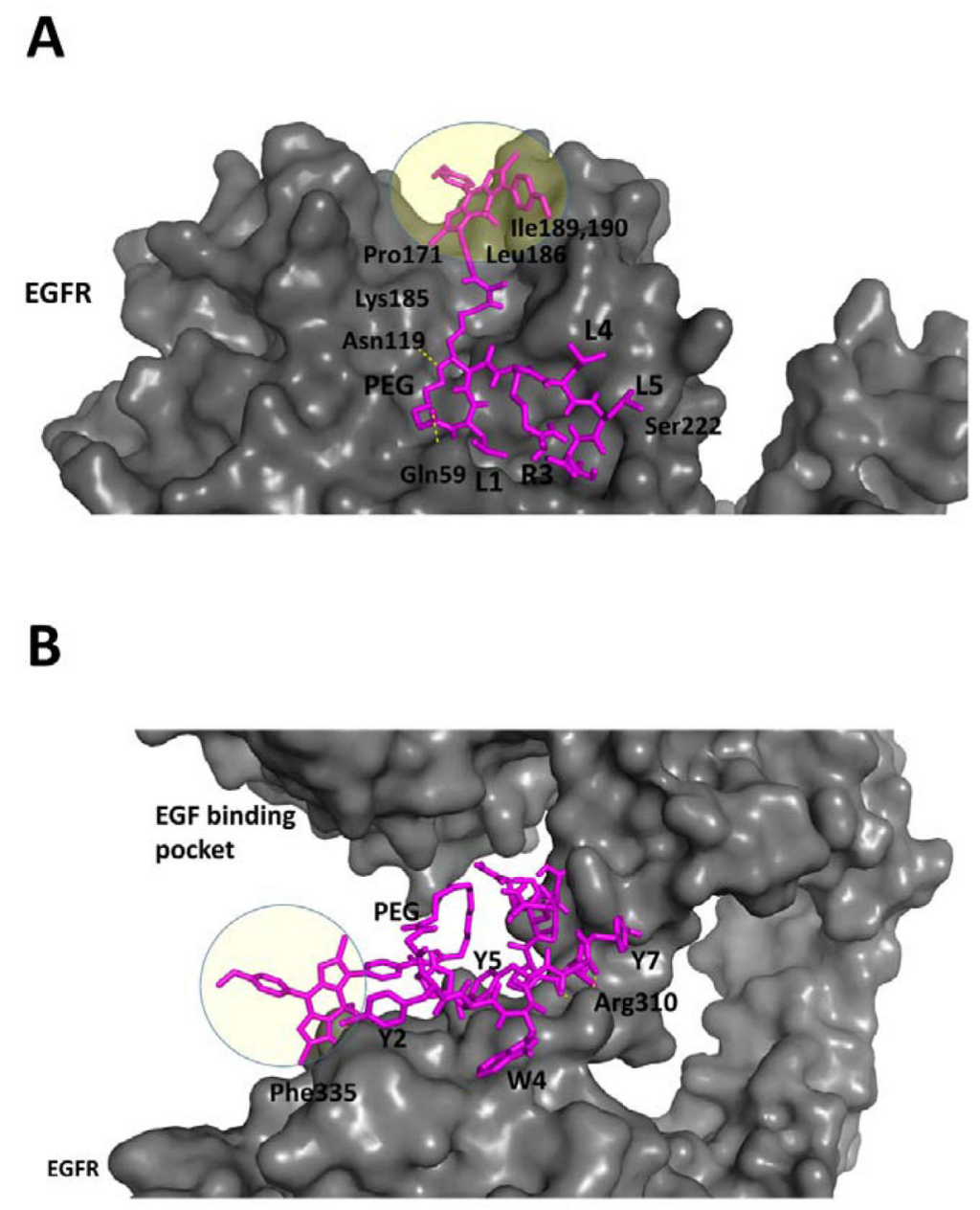

Figure 8.

Proposed model of interaction of EGFR with A) conjugate 8 and B) conjugate $\mathbf{9}$. The BODIPY moiety is highlighted. The peptide amino acids are represented by a single letter code, and the protein amino acids are represented with a three letter code. The EGFR protein is shown in a surface representation. 

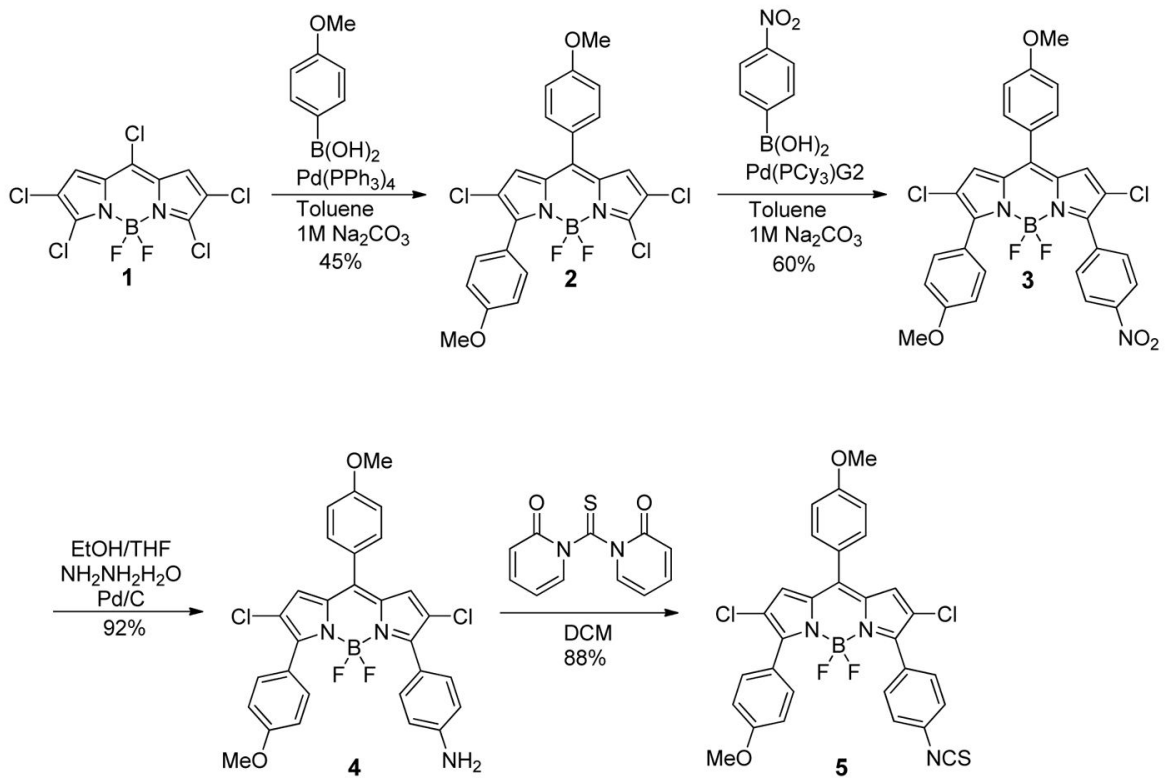

Scheme 1.

Synthesis of isothiocyanato-functionalized $\mathbf{5}$. 


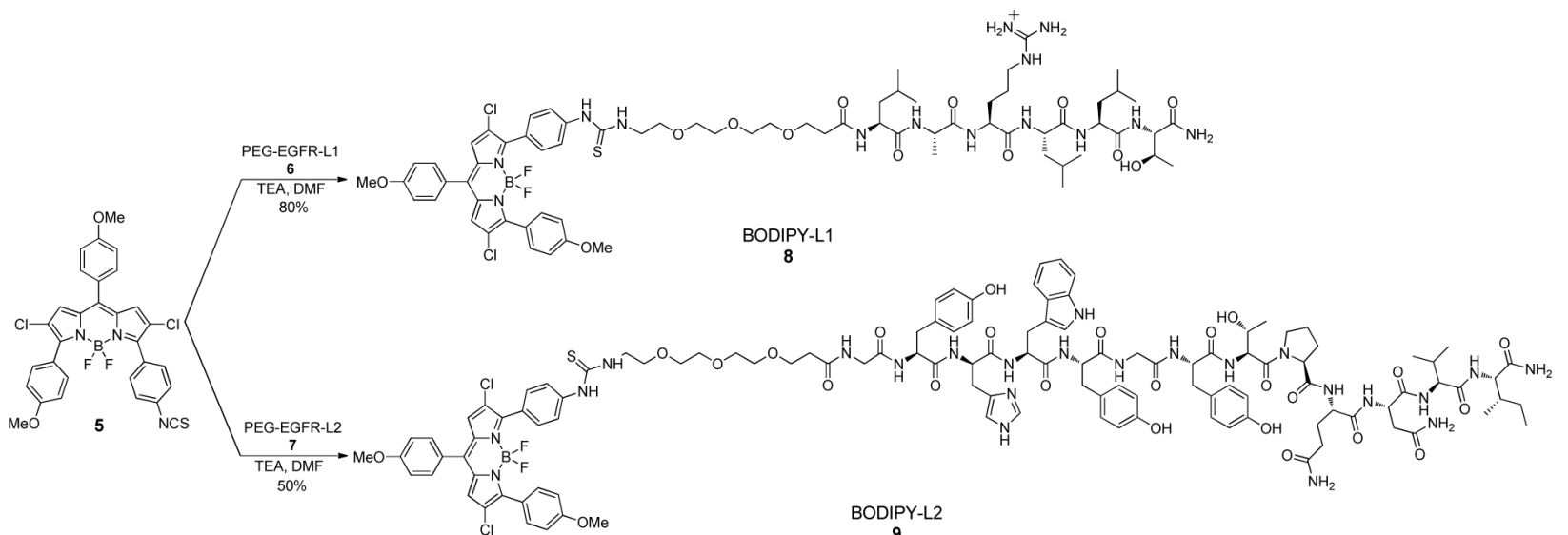

Scheme 2.

Synthesis of peptide conjugates BODIPY-L1 (8) and BODIPY-L2 (9). 

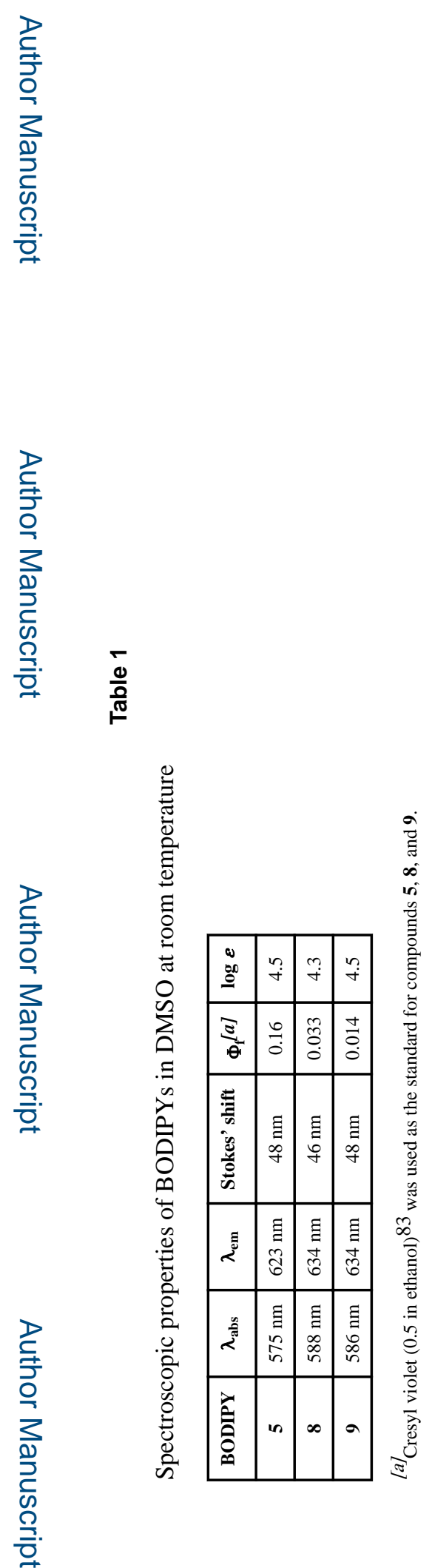


\section{Table 2}

Cytotoxicity for BODIPYs $\mathbf{5 , 8}$ and $\mathbf{9}$ using the Cell Titer Blue assay in human HEp2 cells and their major/ minor subcellular localization sites

\begin{tabular}{c|c|c|c|c}
\hline BODIPY & $\begin{array}{c}\text { Dark toxicity }\left(\mathbf{I C}_{\mathbf{5 0}},\right. \\
\boldsymbol{\mu} \mathbf{M})\end{array}$ & Phototoxicity $\left(\mathbf{I C}_{\mathbf{5 0}}, \boldsymbol{\mu} \mathbf{M}\right)$ & $\begin{array}{c}\text { major sites of subcellular } \\
\text { localization }\end{array}$ & minor sites of subcellular localization \\
\hline $\mathbf{5}$ & $>200$ & $>100$ & ER, Golgi & mitochondria, lysosomes \\
\hline $\mathbf{8}$ & 98 & 74 & Golgi, lysosomes & ER, mitochondria \\
\hline $\mathbf{9}$ & 180 & $>100$ & Golgi, Lysosomes & ER \\
\hline
\end{tabular}

